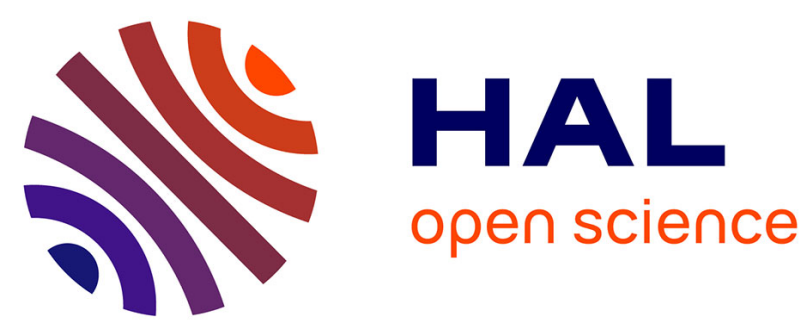

\title{
LC-MS analysis of aerosol particles from the oxidation of ?-pinene by ozone and OH-radicals
}

R. Winterhalter, R. van Dingenen, B. R. Larsen, N. R. Jensen, J. Hjorth

\section{To cite this version:}

R. Winterhalter, R. van Dingenen, B. R. Larsen, N. R. Jensen, J. Hjorth. LC-MS analysis of aerosol particles from the oxidation of ?-pinene by ozone and $\mathrm{OH}$-radicals. Atmospheric Chemistry and Physics Discussions, 2003, 3 (1), pp.1-39. hal-00300836

\section{HAL Id: hal-00300836 \\ https://hal.science/hal-00300836}

Submitted on 6 Jan 2003

HAL is a multi-disciplinary open access archive for the deposit and dissemination of scientific research documents, whether they are published or not. The documents may come from teaching and research institutions in France or abroad, or from public or private research centers.
L'archive ouverte pluridisciplinaire HAL, est destinée au dépôt et à la diffusion de documents scientifiques de niveau recherche, publiés ou non, émanant des établissements d'enseignement et de recherche français ou étrangers, des laboratoires publics ou privés. 
3, 1-39, 2003

LC-MS analysis of aerosol particles

R. Winterhalter et al.

\section{LC-MS analysis of aerosol particles from the oxidation of $\alpha$-pinene by ozone and OH-radicals}

R. Winterhalter ${ }^{1,}{ }^{\text {, }}$, R. Van Dingenen ${ }^{1}$, B. R. Larsen ${ }^{1}$, N. R. Jensen ${ }^{1}$, and J. Hjorth ${ }^{1}$

${ }^{1}$ European Commission, Joint Research Centre, Institute for Environment and Sustainability, 21020 Ispra (VA), Italy

*Present address: Max-Planck-Institut für Chemie, Atmospheric Chemistry Division, Mainz, Germany

Received: 9 October 2002 - Accepted: 9 December 2002 - Published: 6 January 2003

Correspondence to: R. Winterhalter (winterha@mpch-mainz.mpg.de)

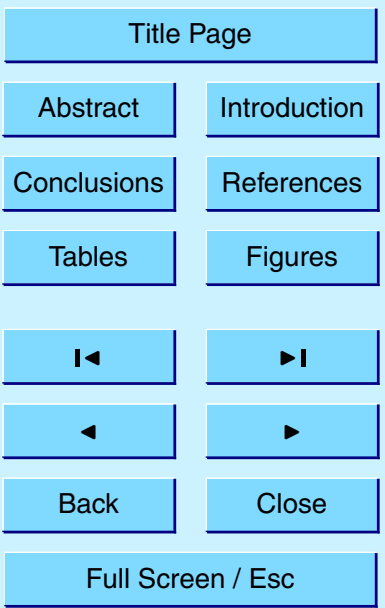

Print Version

Interactive Discussion

(C) EGU 2003 


\section{Abstract}

The time resolved chemical composition of aerosol particles, formed by the oxidation of $\alpha$-pinene has been investigated by liquid chromatography/mass spectrometry (LC-MS) using negative and positive ionisation methods (ESI(-) and $\mathrm{APCl}(+))$. The experiments 5 were performed at the EUPHORE facility in Valencia (Spain) under various experimental conditions, including dark ozone reactions, photosmog experiments with low $\mathrm{NO}_{\mathrm{x}}$ mixing ratios and reaction with $\mathrm{OH}$ radicals in the absence of $\mathrm{NO}_{x}\left(\mathrm{H}_{2} \mathrm{O}_{2}\right.$-photolysis). Particles were sampled on PTFE filters at different stages of the reaction and extracted with methanol. The predominant products from $\alpha$-pinene in the particulate phase are pound with molecular weight 172 was detected, possibly a hydroxy-carboxylic acid. These major compounds account for $50 \%$ to $80 \%$ of the identified aerosol products, depending on the time of sampling and type of experiment. In addition, more than 20 different products have been detected and structures have been tentatively assigned based on their molecular weight and responses to the different ionisation modes. The different experiments performed showed that the aerosol formation is mainly caused by the ozonolysis reaction. The highest aerosol yields were observed in the dark ozone experiments, for which also the highest ratios of mass of identified products to the formed aerosol mass were found ( $30 \%$ to $50 \%$, assuming a density of $1 \mathrm{~g} \mathrm{~cm}^{-3}$ ).

\section{Introduction}

Secondary organic aerosol (SOA) formation from oxidation of biogenic compounds (mainly from monoterpenes like $\alpha$-pinene) contributes considerably to the total atmospheric aerosol burden. Since the aerosol particles influence the radiative transfer of the earth directly by light scattering and absorption or indirectly by serving as condensation nuclei for the formation of cloud droplets, it is necessary to know the sources and the amount of the different types of aerosol in order to improve models dealing with
ACPD

3, 1-39, 2003

\section{LC-MS analysis of} aerosol particles

R. Winterhalter et al.

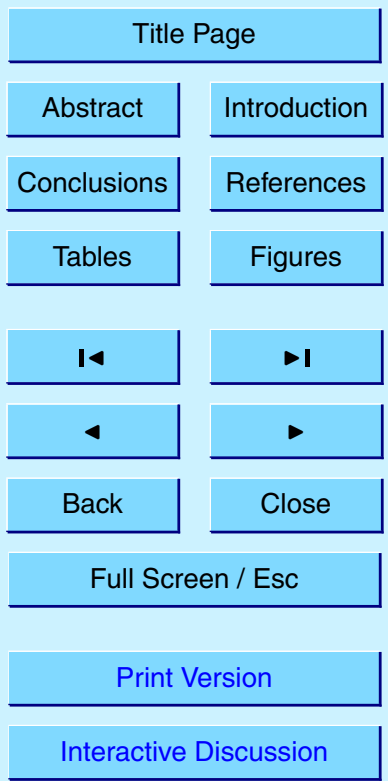

(C) EGU 2003 
climate change.

The estimates of the global annual SOA formation by biogenic compounds are very uncertain, ranging from 13-24 Tg (Griffin et al., 1999b) to 30-270 Tg (Andreae and Crutzen, 1997). In a recent study the present day annual biogenic SOA formation 5 was estimated to be $61-79 \mathrm{Tg} \mathrm{yr}^{-1}$ compared to pre-industrial levels of $17-28 \mathrm{Tg} \mathrm{yr}^{-1}$ (Kanakidou et al., 2000). This increased post-industrial level of biogenic SOA formation is due to anthropogenic influences, which cause increased ozone concentrations and as a consequence also increased aerosol formation. The uncertainties of the estimates comprise uncertainties in the amount of globally emitted biogenic compounds as well 10 as uncertainties of the amount of SOA formed upon atmospheric oxidation of these biogenic compounds.

Among the various biogenic compounds, only terpenes are believed to be a significant source of secondary organic aerosol under atmospheric conditions. The most reactive compounds are the monoterpenes and sesquiterpenes. Although the variety 15 of emitted monoterpenes is high, the predominant species are $\alpha$-pinene, $\beta$-pinene and limonene (Guenther et al., 1995). Since these compounds are unsaturated, they are rapidly oxidised in the atmosphere by ozone, $\mathrm{OH}$ - and $\mathrm{NO}_{3}$-radicals (Atkinson, 1994).

The reaction of ozone and monoterpenes has been proposed as a potential aerosol source already in 1960 (Went, 1960). Besides the dark ozone reaction also the reactions with $\mathrm{OH}$ and $\mathrm{NO}_{3}$ radicals lead to aerosol formation (Hoffmann et al., 1997; Griffin et al., 1999a; Larsen et al., 2001). The non-volatile oxidation products, like higher organic acids, condense onto existing particles, which can be described by the gas-particle partitioning model (Odum et al., 1996). The oxidation of biogenic compounds might also lead to the formation of new particles in rural areas as field studies 25 indicate (Mäkelä et al., 1997). Several oxidation products of $\alpha$-pinene and $\beta$-pinene have been found in aerosol particles collected over forested areas (Kavouras et al., 1998; Kavouras et al., 1999a; Kavouras et al., 1999b; Pio et al., 2001a; Pio et al., 2001b).

The atmospheric oxidation of $\alpha$-pinene has been studied under several aspects so

\section{LC-MS analysis of aerosol particles}

R. Winterhalter et al.

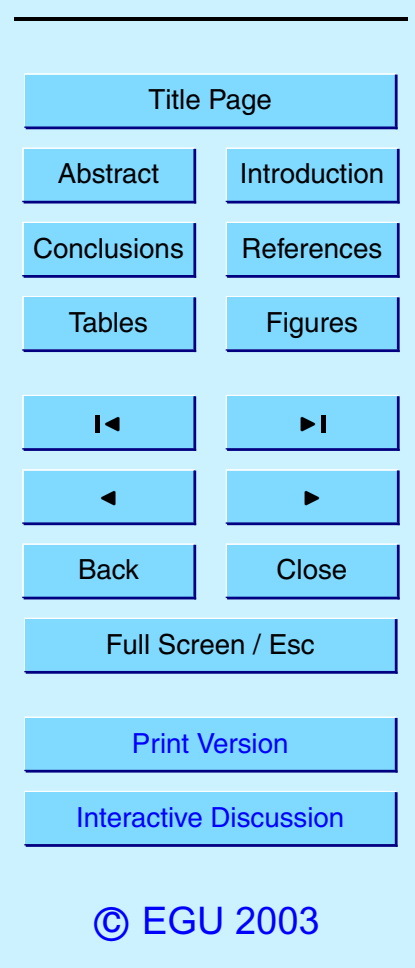


far. Laboratory studies using FTIR (Hatakeyama et al., 1989; Hatakeyama et al., 1991), GC/MS (Hull, 1981; Jay and Stieglitz, 1987; Hakola et al., 1994) report gas-phase products like pinonaldehyde and pinonic acid. The particulate phase has been studied by GC/MS after derivatisation of carboxylic acids and the very non-volatile dicarboxylic

5 acid pinic acid was identified (Christoffersen et al., 1998). Further studies found additional acids like hydroxy-pinonic and norpinic acid (Jang and Kamens, 1998; Yu et al., 1999; Glasius et al., 2000; Koch et al., 2000; Larsen et al., 2001).

Despite the considerable improvement of the understanding of the gas-phase oxidation of $\alpha$-pinene, there is still a lack of understanding of the aerosol forming products 10 and mechanism. In this study the evolution of the aerosol chemical composition was investigated in three types of experiments. The dark reaction of $\alpha$-pinene with ozone and the reaction with $\mathrm{OH}$-radicals in the absence of $\mathrm{NO}_{\mathrm{x}}$ was studied as well as photosmog experiments with various initial $\mathrm{NO}_{\mathrm{x}}$-concentrations.

\section{Experimental}

\subsection{Experimental set-up}

The experiments were performed at the EUPHORE facilities in Valencia, Spain. The two $200 \mathrm{~m}^{3}$ reaction chambers are equipped with various analytical instruments for the on-line (FTIR-spectroscopy, gas-chromatography, $\mathrm{O}_{3}-$, $\mathrm{NO}_{x}$-analyser) and off-line analysis (sampling with cartridges) of gaseous compounds and with instruments for the determination of physical parameters (temperature, pressure, relative humidity, light intensity, etc.). Details of the instrumentation can be found elsewhere (Brockmann et al., 1996).

The particle size distribution was measured with a differential mobility analyser (DMA) in order to measure the aerosol volume formed by the reaction of $\alpha$-pinene with the different oxidants. The terpene concentration was determined by FTIR and gas-chromatography. The conditions of the various experiments are displayed in Ta-

\section{LC-MS analysis of aerosol particles}

R. Winterhalter et al.

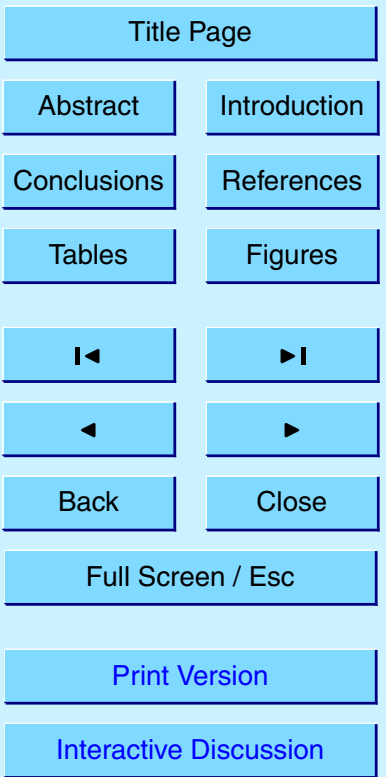


ble 1. The photosmog experiments were performed in the presence of ammonium sulfate seed aerosol, whereas the ozonolysis experiments were performed without seed aerosol. Most of the experiments were performed under dry conditions, but a few experiments have been repeated under humid conditions (relative humidity $45 \%-49 \%$ ).

5 2.2. Sampling method and sample preparation

The particles were sampled with Teflon-filters (PTFE), $47 \mathrm{~mm}$ in diameter and with a pore-size of $1 \mu \mathrm{m}$. An aluminium pipe ( $50 \mathrm{~mm}$ diameter, $1 \mathrm{~m}$ length) was used as sampling line, with the inlet placed roughly $50 \mathrm{~cm}$ above the floor of the reaction chamber, in vicinity of the sampling lines connected to the DMA.

10 The particles were collected with flow rates of $27-301 \mathrm{~min}^{-1}$ (Chamber A) and 35$381 \mathrm{~min}^{-1}$ (Chamber B) using Andersen pumps in combination with a gas meter to determine the volume. Additionally, a differential pressure gauge was used to measure the pressure before and after the filter (usually between 130 and 200 mbar), which is necessary to calculate the corrected sample volume at atmospheric pressure. The 15 volumes of the sampled air ranged from $0.2 \mathrm{~m}^{3}$ to $7 \mathrm{~m}^{3}$, depending on the desired time intervals of the filter samples and the available amount of formed aerosol.

Immediately after the collection of the particles, the filters were put into glass vials with $2 \mathrm{ml}$ of solvent (methanol, containing $0.1 \% \mathrm{NH}_{3}$ ), sealed and stored in the refrigerator at $5^{\circ} \mathrm{C}$. Prior to analyses the samples have been shaken for $24 \mathrm{~h}$. After removal of

the filters the volume of the extracts was reduced to $250 \mu$ l with a gentle N2-flow at room temperature. Finally $750 \mu$ l water containing $1 \%$ acetic acid were added to achieve the same methanol/water ratio as in the initial HPLC-eluent mixture (see below).

In order to determine the extraction efficiency, filters with the highest aerosol loading were extracted a second time with methanol and treated as described. Only main
ACPD

3, 1-39, 2003

\section{LC-MS analysis of aerosol particles}

R. Winterhalter et al.

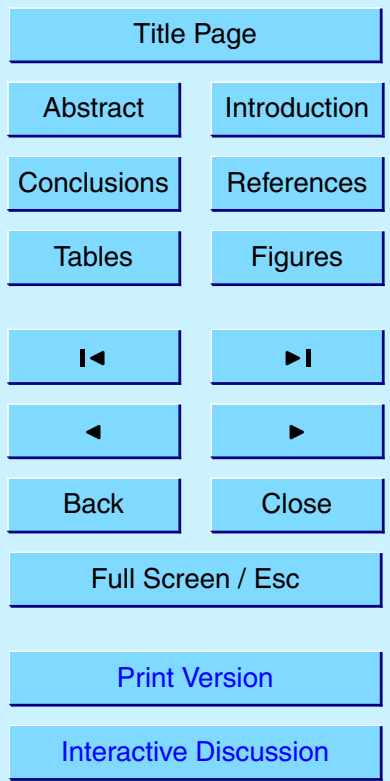

(C) EGU 2003 because their concentrations were below the detection limit (at $S / N=3$ ) of $5 \mathrm{ng} \mathrm{ml}^{-1}$ in the ESI(-)-mode. 
The filter extracts were analysed by liquid chromatography-mass spectrometry (LCMS). Aliquots $(50 \mu \mathrm{l})$ of extract were loop injected into a ThermoSeparation HPLC coupled to a Finnigan Mat LCQ ion-trap mass spectrometer. The HPLC was equipped

5 with a thermostated $\left(20^{\circ} \mathrm{C}\right) 15 \mathrm{~cm} \times 2.1 \mathrm{~mm}$ C18-coated silica gel $(5 \mu \mathrm{m})$ column run in the gradient mode $\left(0.3 \mathrm{ml} \mathrm{min}^{-1}\right)$ programmed from $25 \%$ to $75 \%$ methanol in $17.5 \mathrm{mM}$ acetic acid in $20 \mathrm{~min}$. Acetonitrile, another common eluent for LC-MS analysis of organic acids, could not be used, since prior test of HPLC grade acetonitrile (SigmaAldrich) revealed impurities with the same masses as products from $\alpha$-pinene $\left(\mathrm{M}_{\mathrm{w}}\right.$ 10 184, 186).

For the detection of products two different ionisation techniques were applied. Each sample was analysed twice, using the $\mathrm{ESI}(-)$ - and $\mathrm{APCl}(+)$-mode, respectively, as ionisation method in order to gather information about functional groups in unknown products. In a first run the outlet of the HPLC was split (3:1) to the ESI (pneumatically 15 assisted electrospray ionisation) interface with $\mathrm{N}_{2}$ as sheath gas and He as auxiliary gas. This ionisation method has a high sensitivity for organic acids, forming either the deprotonised molecular ion $[\mathrm{M}-\mathrm{H}]^{-}$or the adduct with acetic acid $[\mathrm{M}-\mathrm{H}+60]^{-}$. In a second run, atmospheric pressure chemical ionisation in the positive mode $(\mathrm{APCl}(+))$ was used as ion source, which is applicable for the detection of carbonyls and alcohols. In contrast, the proton affinity of organic acids is too low to form ions in the $\mathrm{APCl}(+)$ mode (Glasius et al., 1999).

Available standards are pinic acid $\left(M_{w} 186\right)$, pinonic acid $\left(M_{w} 184\right)$, and pinonaldehyde $\left(M_{w}\right.$ 168). For the quantification of unknown acids an average response factor of pinic and pinonic acid was used, for unknown carbonyl compounds the response factor of pinonaldehyde. Molecules, which give a signal with both ionisation methods, were quantified based on their stronger ESI(-) signal.

\section{LC-MS analysis of aerosol particles}

R. Winterhalter et al.

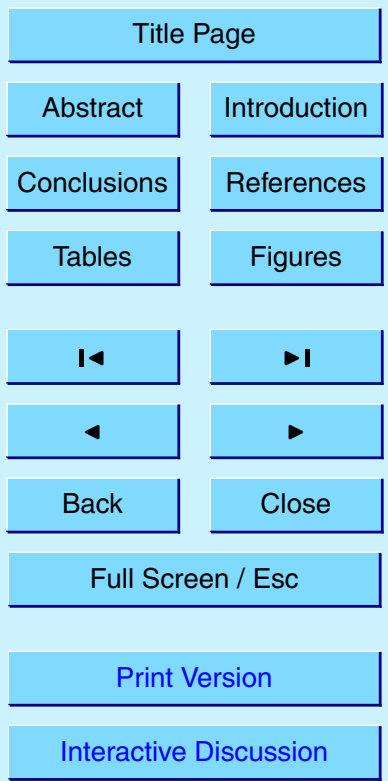

(C) EGU 2003 


\section{Results and discussion}

\subsection{General observations and identified products}

In samples taken under conditions with high aerosol volume concentrations, where only short sampling times were necessary to collect sufficient amounts of particles, 5 numerous compounds have been detected. The experiments with the highest aerosol volume are the three ozonolyses of $\alpha$-pinene (Experiments 0210A, 0410A, and 0510A, see Table 1$)$, where even with relatively small sampling volumes $\left(0.3-0.7 \mathrm{~m}^{3}\right)$ good results were obtained.

In the photosmog experiments the formation of aerosol was much slower than in 10 the ozonolysis experiments. Due to the slow formation of particles and the relatively fast loss rate of particles in the ventilated reaction chamber, the low aerosol volume concentrations made much longer sampling times necessary. In these samples the main products could be detected, but the concentrations of minor products were in most samples below the detection limit.

15 The duration of sampling is a crucial factor for the obtained mass balances of detected products in the aerosol phase. Due to the pressure drop over the filter, particulate products are prone to evaporation at the lower pressure side of the filter and due to the air flow an equilibrium between gas and liquid (or particulate) phase is not established. Therefore the evaporative loss of products (negative artefact), especially of semi-volatile compounds, leads to the poor mass balances in these cases. This effect is demonstrated in Fig. 1, where the mass balance (sum of products/(sample volume $x$ aerosol mass concentration)) of each filter sample from $\alpha$-pinene experiments in both chambers is plotted versus the duration of sampling.

It is evident, that the mass balances obtained from samples of the three ozonolysis
ACPD

3, 1-39, 2003

\section{LC-MS analysis of aerosol particles}

R. Winterhalter et al.

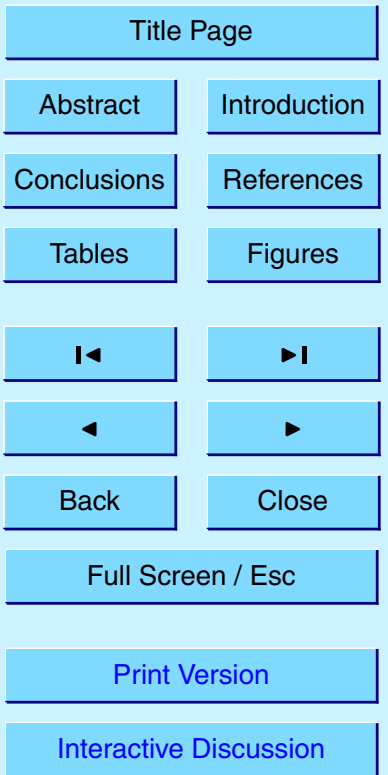

(C) EGU 2003 aerosol (SOA) is formed rapidly in contrast to the much slower and weaker formation in case of the photosmog experiments. The available SOA mass in the ozonolysis 
experiments allows much shorter sampling times compared to the photosmog experiments with less SOA mass and consequently longer sampling times in order to sample sufficient SOA with the filter.

A typical chromatogram of a sample analysed in the ESI(-) mode is shown in Fig. 2, 5 displaying the total ion current (TIC) and extracted ions for the most abundant products detected. In all samples cis-pinic acid is one of the main products, detected as $[\mathrm{M}-\mathrm{H}]^{-}$ at $\mathrm{m} / \mathrm{z} 185$. Due to the steric configuration of the carboxylic groups in cis-pinic acid, the adduct formation with acetic acid $[\mathrm{M}-\mathrm{H}+60]^{-}$is suppressed by intramolecular hydrogen bonding (Glasius et al., 1999). The other conformer of pinic acid, trans-pinic acid, is 10 detected as the acetic acid adduct $[\mathrm{M}-\mathrm{H}+60]^{-}$, since intramolecular hydrogen bonding is impossible because of the trans configuration of the carboxylic acid groups. The authentic sample of pinic acid contains both cis- and trans-pinic acid, which can be distinguished due to the different detected ions. In none of the samples trans-pinic acid was detected, in accordance with the chemical reaction mechanism and the original configuration of $\alpha$-pinene (see Sect. 3.5).

Another product for which an authentic sample is available is pinonic acid detected as $[\mathrm{M}-\mathrm{H}]^{-}$at $\mathrm{m} / \mathrm{z} 183$ and as acetic acid adduct $[\mathrm{M}-\mathrm{H}+60]^{-}$at $\mathrm{m} / \mathrm{z} 243$. As can be seen in Fig. 2, there are also other small peaks at different retention times with $\mathrm{m} / \mathrm{z}$ 183 and 243. The origin of these peaks remains hidden, but none of these compounds were found in blank samples (filter material, chamber impurities, used solvents) and it is reasonable to conclude that they are either primary reaction products or they are formed by secondary reactions during sample preparation.

At $\mathrm{m} / \mathrm{z} 171[\mathrm{M}-\mathrm{H}]^{-}$and $231[\mathrm{M}-\mathrm{H}+60]^{-}$there are four peaks, three minor and one major one at retention time $2.45 \mathrm{~min}$, whose intensity is comparable to the one of pinic acid. A known product with molecular weight 172 is norpinic acid, like pinic acid a dicarboxylic acid which can not be detected in the $\mathrm{APCI}(+)$ mode. The TIC and extracted ion chromatogram of the same sample as in Fig. 2, but analysed in the $\mathrm{APCl}(+)$ mode is shown in Fig. 3. At $\mathrm{m} / \mathrm{z} 173[\mathrm{M}+\mathrm{H}]^{+}$a major peak at the same retention time as for the major peak in the ESI(-) mode was found, indicating that this compound cannot
ACPD

3, 1-39, 2003

\section{LC-MS analysis of aerosol particles}

R. Winterhalter et al.

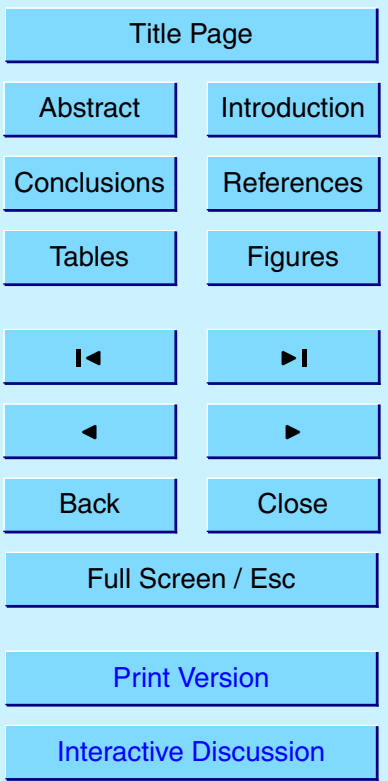

(C) EGU 2003 
be norpinic acid. A possible structure for this major product is 3-(2-hydroxy-ethyl)-2,2dimethyl-cyclobutanecarboxylic acid with Mw 172, the carboxylic acid group gives a signal in the $\mathrm{ESI}(-)$ and the hydroxy group a signal in the $\mathrm{APCl}(+)$ mode). According to the Larsen nomenclature (Larsen et al., 1998) this compound could be named "pinolic 5 acid" in analogy to pinalic acid, but it should be noted that this name is already used in the literature for [3-(1-hydroxy-ethyl)-2,2-dimethyl-cyclobutyl]-acetic acid (named analogue to pinonic acid, [3-acetyl-2,2-dimethyl-cyclobutyl]-acetic acid).

The retention times, observed signals in the $\mathrm{ESI}(-)$ and/or $\mathrm{APCl}(+)$ ionisation mode of $\alpha$-pinene oxidation products and possible identifications are given in Table 2. Besides 10 the major products pinic acid, pinonic acid, $\mathrm{OH}$-pinonic acid, $\mathrm{M}_{\mathrm{w}} 172$, and pinonaldehyde numerous compounds have been detected. The possible assignments are based on the responses to the different ionisation methods.

Minor acidic products at $\mathrm{m} / \mathrm{z} 169+229$ correspond to pinalic acid (two possible isomers) and norpinonic acid, but the assignment is impossible without reference com15 pounds. Also two intense peaks corresponding to $\mathrm{OH}$-pinonic acid (three isomers) at $\mathrm{m} / \mathrm{z} 199+259$ were detected, for keto-pinonic acid (two isomers) at $\mathrm{m} / \mathrm{z} 197+257$, the observed peaks are much less intense.

The dominant product among the non-acidic compounds, detected by $\mathrm{APCl}(+)$, is pinonaldehyde at $\mathrm{m} / \mathrm{z} 169[\mathrm{M}+\mathrm{H}]^{+}$(RT $\left.5.35 \mathrm{~min}\right)$, confirmed by an authentic standard.

20 There were also other compounds detected at this $\mathrm{m} / \mathrm{z}$ value, the most intense at RT 6.00 min (Fig. 3). Two possible products are 2-hydroxy-3-pinanone, which was identified as a product from the reaction of $\alpha$-pinene and the $\mathrm{OH}$-radical (Jaoui and Kamens, 2001) and 8-hydroxy-menthen-6-one (5-(1-hydroxy-1-methyl-ethyl)-2-methylcyclohex-2-enone), which has been predicted by a theoretical study (Vereecken and 25 Peeters, 2000; Peeters et al., 2001).

Minor products are OH-pinonaldehyde (three isomers) at $\mathrm{m} / \mathrm{z} 185$ and ketopinonaldehyde (two isomers) at $\mathrm{m} / \mathrm{z} 183$. Other possible products at $\mathrm{m} / \mathrm{z} 185$ are the three esters: 2,2-dimethyl-3-(2-oxo-ethyl)-cyclobutanecarboxylic acid methyl ester, formic acid 3-acetyl-2,2-dimethyl-cyclobutyl ester, as tentatively identified by (Yu et al.,

\section{LC-MS analysis of aerosol particles}

R. Winterhalter et al.

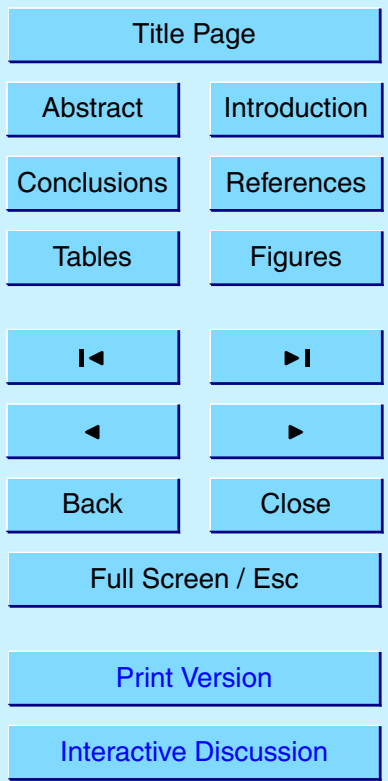

(C) EGU 2003 
1999), and acetic acid 2,2-dimethyl-3-(2-oxo-ethyl)-cyclobutyl ester.

At $\mathrm{m} / \mathrm{z} 187[\mathrm{M}+\mathrm{H}]^{+}$several peaks were detected, and one of these compounds (RT $6.00 \mathrm{~min}$ ) was possibly also observed in the ESI(-) mode, as can be seen at the shoulder in the pinic acid peak (Fig. 2). Expected products from $\alpha$-pinene oxidation are the

5 two hydroperoxides (2-hydroperoxy-3-hydroxy-pinane (2-hydroperoxy-2,6,6-trimethylbicyclo [3.1.1] heptan-3-ol) and 3-hydroperoxy-2-hydroxy-pinane (3-hydroperoxy-2,6,6trimethyl-bicyclo [3.1.1] heptan-2-ol), note that two isomers exist of each compound, so in principle four possible products and peroxo-pinalic acid (2,2-dimethyl-3-(2-oxoethyl)-cyclobutane-carboperoxoic acid).

10 In the following sections the yields of particulate products are presented for the different experiments. In order to derive the formation yield the measured product mixing ratios had to be corrected for loss processes and extraction efficiency. The correction for the extraction efficiency was done with a mean value of $90 \%$ for all products. For correction of aerosol loss the ratio of corrected to measured SOA was used. Finally the 15 yield of particulate products was calculated versus reacted $\alpha$-pinene, which has been corrected for loss processes by the use of the chemically inert tracer $\mathrm{SF}_{6}$.

\subsection{Ozonolysis experiments and ageing of aerosol}

Three ozonolysis experiments have been conducted with $\alpha$-pinene in the dark in order to study the chemical composition of the aerosol in the absence of seed aerosol. After 20 the formation of SOA, when the reaction slowed down, $\mathrm{NO}_{\mathrm{x}}$ and $\mathrm{HCHO}$ were introduced into the reaction chamber and the cover of the chamber opened to study the changes of the aerosol composition upon oxidation of the aerosol (ageing).

The time profile of ozone and reacted $\alpha$-pinene of an ozonolysis experiment (0210A) is shown in Fig. 4a together with the measured and corrected aerosol volume and 25 the duration of filter sampling. Also shown is the calculated amount of ozone that has reacted with $\alpha$-pinene (reacted ozone). Immediately after introduction of ozone the particle formation started and after the conversion of $80 \mathrm{ppb} \alpha$-pinene roughly $120 \mu \mathrm{m}^{3} \mathrm{~cm}^{-3}$ of SOA had been formed. At this stage $\mathrm{NO}_{\mathrm{x}}$ and $\mathrm{HCHO}$ were added,

\section{LC-MS analysis of aerosol particles}

R. Winterhalter et al.

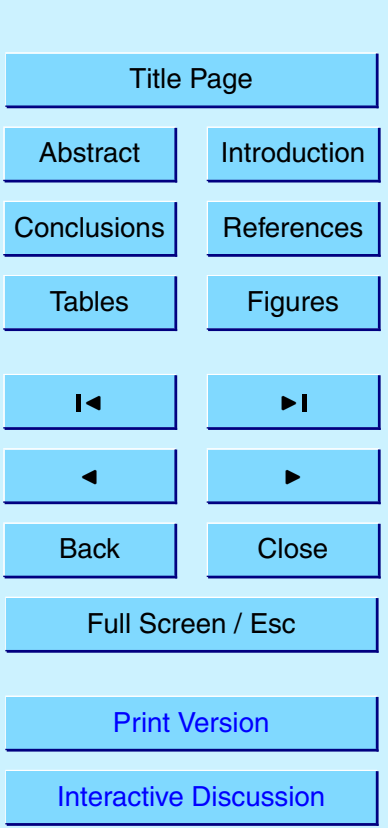

(C) EGU 2003 
which can be seen in Fig. 4a by the sudden decrease of ozone (at 12:40) due to the reaction with NO.

The results of LC-MS analysis are represented in Fig. 4b, the first two samples were ACPD taken during the initial aerosol formation (nucleation and coagulation) with short sam5 pling times. The third sample was taken when more than $80 \%$ of $\alpha$-pinene had been reacted. The fourth sample was taken after consumption of $\alpha$-pinene and the fifth sample after ageing of the aerosol by photo-oxidation.

The predominant aerosol products are pinic, pinonic, $\mathrm{OH}$-pinonic acid and an acid with $M_{w} 172$. These compounds account for $70 \%$ to $80 \%$ of the identified aerosol 10 products. The aerosol yield (SOA mass/reacted $\alpha$-pinene mass) increased from 10\% to $24 \%$, as well as the sum of the product yields, which increases from 2 to $7 \%$.

The yield of pinic acid increases from 0.5 to $2 \%$ and is the range of the results from other studies, reporting 1.4\% (Glasius et al., 2000), 3 to 6\% (Yu et al., 1999), and 3.2\% (Koch et al., 2000). Also the yield of pinonic and OH-pinonic acid are in the range of 15 other studies. No other study reports the formation of a product with $M_{w} 172$, except norpinic acid, which was found to be only a minor product in this study. The yields of particulate products from the ozonolysis of $\alpha$-pinene from other studies are listed in Table 4.

The effect of ageing is difficult to determine, since the observed changes are within 20 the error range of the analytical method. Furthermore, there are still reactive gas phase compounds present competing with the particle bound products for the $\mathrm{OH}$-radical. Therefore it is likely that only a small fraction of particle bound products (presumable only at the surface of the particle, due to the high reactivity of the $\mathrm{OH}$-radical) was actually oxidised. Nevertheless, changes in the yields of pinonaldehyde, $\mathrm{OH}$-pinonaldehyde 25 and keto-pinonaldehyde as well as the corresponding acids were observed. In course of the ageing experiment the aldehydes decrease and the acids increase as a result of the oxidation of the aldehydes. But it cannot be distinguished if the oxidation occurs in the particulate or in the gas-phase or in both phases.

\section{LC-MS analysis of aerosol particles}

R. Winterhalter et al.

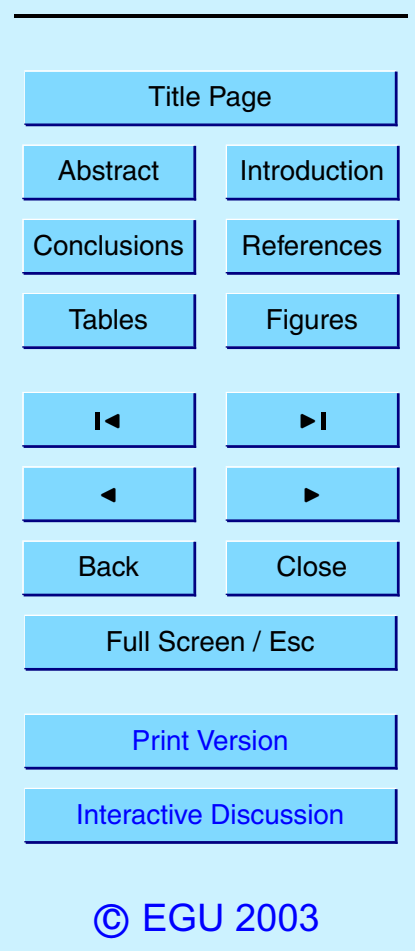


The so-called photosmog experiments were performed under various experimental conditions (Table 1), varying $\mathrm{NO}_{x}$ mixing ratios and relative humidity. In all of these photosmog experiments seed aerosol was introduced prior to the experiment. Figure $5 \mathrm{a}$

5 displays the time profile for a photosmog experiment (2709A) under dry conditions with an initial $\mathrm{NO}_{\mathrm{x}}$ mixing ratio of $11 \mathrm{ppb}$.

The formed aerosol volume in this kind of experiment is lower than in the dark ozonolysis (Fig. 4a), although the amount of reacted $\alpha$-pinene is comparable in both experiments. At the end of the photosmog experiment $80 \mathrm{ppb} \alpha$-pinene have been reacted 10 and an aersosol volume of $33 \mu \mathrm{m}^{3} \mathrm{~cm}^{-3}$ was formed. In the ozonolysis experiment $90 \mathrm{ppb} \alpha$-pinene was consumed but the aerosol volume is with $150 \mu \mathrm{m}^{3} \mathrm{~cm}^{-3}$ five times higher.

The product yields in the aerosol phase are shown in Fig. $5 b$ together with the aerosol mass yields. The overall product yield increases from $0.1 \%$ to $1.1 \%$. Also 15 in this experiment pinic, pinonic and $\mathrm{OH}$-pinonic acid and the acid with $\mathrm{Mw} 172$ are the main products and account for $80 \%$ of the identified aerosol mass. The results of the photosmog experiments with the highest identified product yields are given in Table 5.

Organic nitrates, which are expected to be formed under these conditions, might also contribute to the aerosol phase, but were not detected with the applied method. The functional groups - $\mathrm{ONO}, \mathrm{OONO},-\mathrm{ONO}_{2},-\mathrm{OONO}_{2}$ and $-\mathrm{C}(\mathrm{O}) \mathrm{OONO}_{2}$ are lacking an hydrogen atom and are therefore not ionised with the $\mathrm{ESI}(-)$ mode. In the $\mathrm{APCl}(+)$ mode, ionisation by proton transfer is expected to occur, but no ions were observed at even $\mathrm{m} / \mathrm{z}$ values. Note that all compounds with only $\mathrm{H}, \mathrm{C}$, and $\mathrm{O}$-atoms have odd $\mathrm{m} / \mathrm{z}$ values: One reason could be that the organic nitrate compound fragments after ionisation into 25 e.g. $\mathrm{NO}_{3}^{+}$and a neutral oxygenated hydrocarbon, which cannot be detected. Another reason could be that the nitrates are not stable in the used solvents and decompose during sample preparation and/or analysis.

\section{LC-MS analysis of aerosol particles}

R. Winterhalter et al.

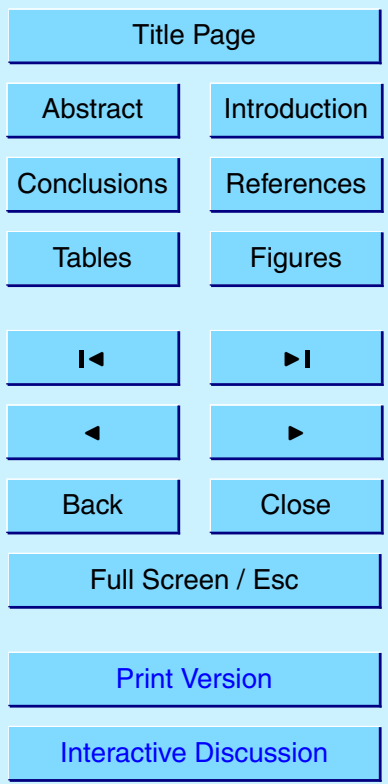

(C) EGU 2003 
In order to study solely the reaction with $\mathrm{OH}$-radicals, an experiment with $20 \mathrm{ppm}_{2} \mathrm{O}_{2}$ as source of $\mathrm{OH}$ radicals was performed in the presence of seed aerosol. The aerosol formation is slightly enhanced compared to the photosmog experiment (Fig. 6a). Al-

5 though, no $\mathrm{NO}_{x}$ was added before the experiment ozone formation is observed due to the fact that in course of a photolysis experiment the $\mathrm{NO}_{\mathrm{x}}$ concentration increases caused by wall impurities. Since the ozone formation is much slower than in the photosmog experiments in the presence of $\mathrm{NO}_{x}$, the ozonolysis reaction plays only a minor role, most of the $\alpha$-pinene had already reacted before sufficient ozone has been formed.

The observed product distribution differs from the ozonolysis and photosmog experiments with the relative contribution of the main products being lower (roughly 50\%). Whereas the relative aerosol composition of the ozonolysis and photosmog are similar, since the main aerosol products arise from the ozone reaction in the photosmog 15 experiment and the contribution of products from the $\alpha$-pinene/OH reaction is rather small.

Larsen et al. (2001) used also $\mathrm{H}_{2} \mathrm{O}_{2}$ photolysis as $\mathrm{OH}$-radical source and found only low yields of particulate products (Table 6). It should be noted that they also report an unidentified compound with $\mathrm{M}_{\mathrm{w}}$ 172. Aerosol mass yields have not been measured in 20 that study.

\subsection{Summary and reaction mechanism of $\alpha$-pinene oxidation}

The majority of observed aerosol products originate from the reaction of ozone and $\alpha$ pinene. Most of the compounds can be explained by the Criegee-mechanism (Criegee, 1975) and consecutive reaction of the instable Criegee-intermediates (Wadt and Goddard, 1975; Martinez et al., 1981; Niki et al., 1987) as illustrated in Fig. 7.

The three important reaction channels for the two Criegee-intermediates in the gas phase are stabilisation and bimolecular reactions with $\mathrm{H}_{2} \mathrm{O}$, the ester channel and the

\section{LC-MS analysis of aerosol particles}

R. Winterhalter et al.

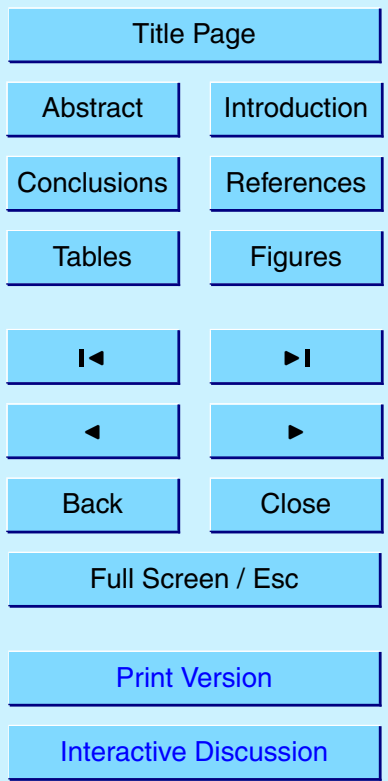

(C) EGU 2003 
hydroperoxide channel. The latter channel leads to the formation of $\mathrm{OH}$-radicals and is therefore the major reaction channel for $\alpha$-pinene ozonolysis as the measured $\mathrm{OH}$ radical yields with 0.85, 0.76 and 0.70 (Atkinson et al., 1992; Chew and Atkinson, 1996; Paulson et al., 1997), respectively, indicate.

There are three possible pathways for rearrangement of $\mathrm{H}$-atoms in the two Criegeeintermediates, leading to three different unsaturated hydroperoxides, which decompose to $\mathrm{OH}$-radicals and alkyl-radicals. The consecutive reactions of these radicals lead to $\mathrm{OH}$-pinonaldehyde (three isomers), keto-pinonaldehyde (two isomers) and norpinonaldehyde.

10 The major channel should be for probabilistic reasons hydroperoxide channel HP 3 (see Fig. 7), since three $\mathrm{H}$-atoms of the methyl-group are available for the rearrangement to the unsaturated hydroperoxide, in contrast to two or one $\mathrm{H}$-atom in case of channel HP 1 and HP 2, respectively. The formation of pinic acid can be explained by two different mechanisms for the acyl-radical, formed in this hydroperoxide chan15 nel. The acyl-radical formed from $\alpha$-pinene is also formed from $\beta$-pinene, although in a different way, the consecutive reactions are identical and in both cases pinic acid is formed (Christoffersen et al., 1998; Winterhalter et al., 2000).

After reaction with $\mathrm{O}_{2}$, the formed peroxy-acyl radical can react with $\mathrm{HO}_{2}$ yielding pinalic and pinalic-peroxo acid, the latter forming pinic acid by intramolecular synpro$20 \quad \mathrm{po}$ portionation (Winterhalter et al., 2000). The reaction of the peroxy-acyl radical with $\mathrm{NO}$ or peroxy-radicals leads to the acyloxy-radical, which either losses $\mathrm{CO}_{2}$ or an intramolecular $\mathrm{H}$-atom abstraction leads to another acyl-radical also yielding pinic acid and peroxo-pinic acid (Jenkin et al., 2000).

Pinonaldehyde is mainly formed by the reaction with $\mathrm{OH}$-radicals, but is also a minor 25 product from the ozonolysis of $\alpha$-pinene in the presence of $\mathrm{H}_{2} \mathrm{O}$. It is reported to be a major or the main product from $\mathrm{OH}$-oxidation with yields ranging from $28 \%$ to $87 \%$ (Arey et al., 1990; Hatakeyama et al., 1991; Hakola et al., 1994; Vinckier et al., 1998; Wisthaler et al., 2001).

Among the products with $\mathrm{M}_{\mathrm{w}} 186$, the two possible $\beta$-hydroxy-hydroperoxides (see

\section{ACPD}

3, 1-39, 2003

\section{LC-MS analysis of aerosol particles}

R. Winterhalter et al.

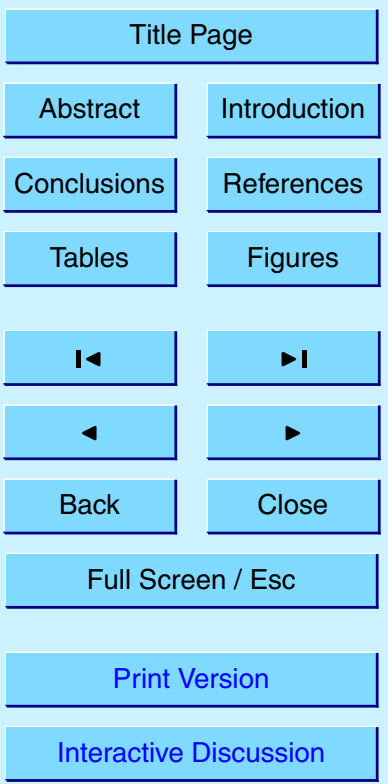

(C) EGU 2003 
Fig. 8) might be formed by the reaction of $\alpha$-pinene with the $\mathrm{OH}$-radical. It should be noted that for each $\beta$-hydroxy-hydroperoxide theoretically two diastereomers (cisand trans-configuration of the $\mathrm{OH}$-and $\mathrm{OOH}$-group) could be formed and four possible compounds with this $\mathrm{M}_{\mathrm{w}}$ exist.

5 The main course of $\alpha$-pinene oxidation proceeds via $\mathrm{OH}$-radical addition to the double bond (88\%). For one of the formed $\mathrm{OH}$-radical adducts there is the possibility to isomerise prior to $\mathrm{O}_{2}$ addition forming a new double bond. The branching ratio of isomerisation to $\mathrm{O}_{2}$ addition is 50:50 (Vereecken and Peeters, 2000; Peeters et al., 2001). Further reactions of the ring-opened radical lead to acetone (not shown in Fig. 8) and

10 8-hydroxy-menthen-6-one. Since this product still contains a double bond it could be also oxidised by $\mathrm{OH}$-radicals to a product with $\mathrm{M}_{\mathrm{w}} 200$ (3-(1-Hydroxy-1-methyl-ethyl)5,6-dioxo-heptanal).

The formation of the OH-pinonic acids and keto-pinonic acids might be due to further oxidation (see Fig. 9) of the corresponding $\mathrm{OH}$-pinonaldehydes and keto15 pinonaldehydes, respectively, which are formed by ozonolysis (Fig. 7). But there has been also reaction mechanisms proposed from the $\mathrm{OH}$-initiated oxidation of $\alpha$-pinene (Larsen et al., 2001).

The formation of norpinic acid cannot be explained by these reaction mechanisms and might be a result of further oxidation of the dialdehyde $\left(M_{w} 140\right)$, which was tentatively identified in prior studies (Jang and Kamens, 1998; Yu et al., 1999). After abstraction of an aldehydic $\mathrm{H}$-atom by an $\mathrm{OH}$-radical the same reaction pathways leading to the formation of pinic acid (Fig. 7) could yield norpinic acid. There is further evidence that the formation of norpinic acid is due to the $\mathrm{OH}$-radical oxidation, since it was only formed in ozonolysis experiments in the absence of an $\mathrm{OH}$-radical scavenger, but not if cyclohexane as OH-radical scavenger was used (Koch et al., 2000).

The origin and identity of the acid with $M_{w} 172$ could not be resolved in this study, but it can be excluded that it is norpinic acid. If the suggested structure (a hydroxycarboxylic acid, see structure 7 in Table $2 b$ ) is correct, there is no plausible reaction pathway leading to this product. Although, it cannot be excluded that this compound

\section{LC-MS analysis of aerosol particles}

R. Winterhalter et al.

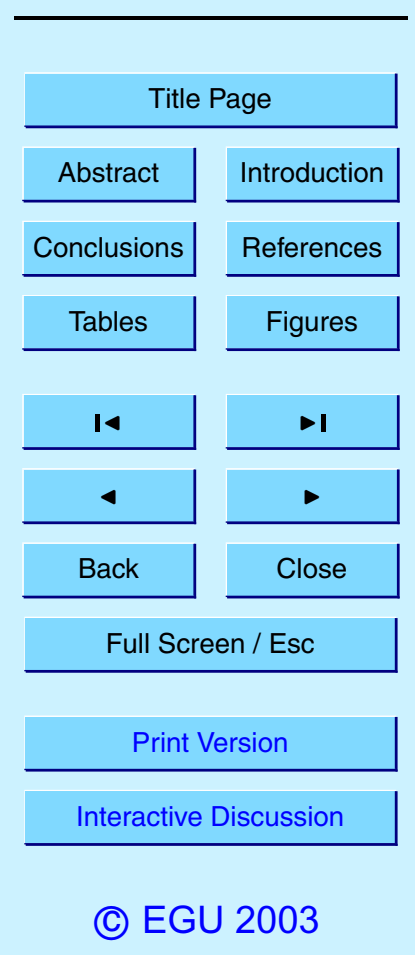


might be an artefact, it seems very unlikely, that it is an artefact related to the large teflon chamber. This compound was neither detected in any of the blank filter samples nor in the experiments performed with limonene at the same time period at EUPHORE.

\section{Conclusions}

5 The atmospheric oxidation of $\alpha$-pinene has been studied under various conditions and the chemical evolution of the aerosol particles was determined. The highest aerosol yields were obtained in the dark ozone reaction indicating the importance of the ozonolysis with regard to aerosol formation. Also the identified products in the photosmog experiments originate mainly from the ozone initiated oxidation of $\alpha$-pinene based on known reaction mechanisms.

Depending on the amount of formed aerosol during the experiments and depending on how much is left at the time of filter sampling, since the loss rates of aerosol are quite high and the sampling times are long, the quality of the analytical results shows some variation. In all experiments of $\alpha$-pinene the main products in the aerosol phase (pinic 15 acid, pinonic acid, $\mathrm{OH}$-pinonic acid, $\mathrm{M}_{\mathrm{w}} 172$, and pinonaldehyde) could be identified in each filter taken. Besides these major products a manifold of minor products could be detected and tentatively assigned. In some samples only a few of these minor compounds could be detected, depending on the sampled aerosol mass, and the rest might be either not formed or the amount was below the detection limit. The best results were obtained in the pure ozone reaction experiments, since they yielded high aerosol masses and therefore enough aerosol to analyse, even with the shortest sampling times applied (14 min).

Acknowledgement. The authors thank the co-workers from CEAM for technical support and assistance during the experiments at EUPHORE. The collaboration by Partners of the OSOA 25 project during the campaign is gratefully acknowledged, especially G. K. Moortgat, A. Römpp, B. Bonn, K. Wirtz, M. Martin-Reviejo, M. Spittler. This study was supported by the Euro-

\section{LC-MS analysis of aerosol particles}

R. Winterhalter et al.

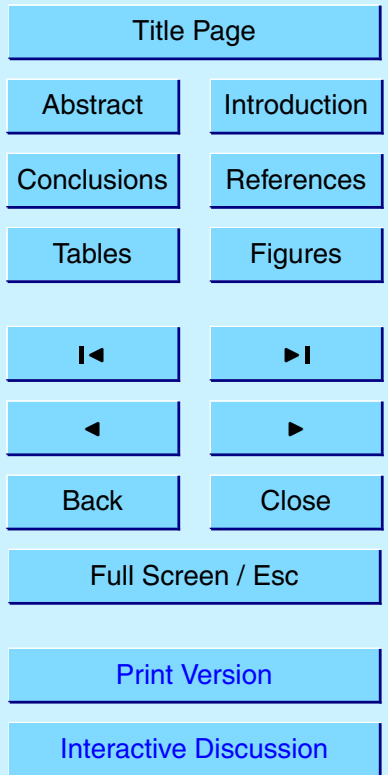

(C) EGU 2003 
pean Commission Environment and Climate Change programme through contract EU-EVK2CT 1999-00016 (OSOA). R. W. acknowledges financial support from the EC.

\section{References}

Andreae, M. O. and Crutzen, P. J.: Atmospheric aerosols: Biogeochemical sources and role in atmospheric chemistry, Science, 276, 1052-1058, 1997.

Arey, J., Atkinson, R., and Aschmann, S. M.: Product study of the gas-phase reactions of monoterpenes with the $\mathrm{OH}$ radical in the presence of NOx, J. Geophys. Res., 95, 1853918546, 1990.

Atkinson, R.: Gas-phase tropospheric chemistry of organic compounds, J. Phys. Chem. Ref. 10 Data, 2, 1-216, 1994.

Atkinson, R., Aschmann, S. M., Arey, J., and Shorees, B.: Formation of $\mathrm{OH}$ radicals in the gas phase reactions of $\mathrm{O}_{3}$ with a series of terpenes, J. Geophys. Res., 97, 6065-6073, 1992.

Brockmann, K. J., Kriesche, V., Etzkom, T., Volkamer, R., and Wirtz, K.: The European Photoreactor EUPHORE: A technical description, in: Proceedings of the EUROTRAC Symposium '96, Borell, P. M., Borell, P., Cvitas, T., Kdelly, K. and Seiler, W. (Eds.), 457-461, 1996.

Chew, A. A. and Atkinson, R.: OH radical formation yields from the gas-phase reactions of $\mathrm{O}_{3}$ with alkenes and monoterpenes, J. Geophys. Res., 101, 28649-28653, 1996.

Christoffersen, T. S., Hjorth, J., Horie, O., Jensen, N. R., Kotzias, D., Molander, L. L., Neeb, P., Ruppert, L., Winterhalter, R., Virkkula, A., Wirtz, K., and Larsen, B. R.: cis-Pinic acid, a possible precursor for organic aerosol formation from ozonolysis of $\alpha$-pinene, Atmos. Environ., 32, 1657-1661, 1998.

Criegee, R.: Mechanismus der Ozonolyse, Angew. Chem., 87, 765-771, 1975.

Glasius, M., Duane, M., and Larsen, B. R.: Determination of polar terpene oxidation products in aerosols by liquid chromatography-ion trap mass spectrometry, J. Chromatography, A 833, 25 121-135, 1999.

Glasius, M., Lahaniati, M., Calogirou, A., Di Bella, D., Jensen, N. R., Hjorth, J., Kotzias, D., and Larsen, B. R.: Carboxylic acids in secondary aerosols from oxidation of cyclic monoterpenes by ozone, Environ. Sci. Technol., 34, 1001-1010, 2000.

Griffin, R. J., Cocker, D. R. I., Flagan, R. C., and Seinfeld, J. H.: Organic aerosol formation from

\section{ACPD}

3, 1-39, 2003

\section{LC-MS analysis of aerosol particles}

R. Winterhalter et al.

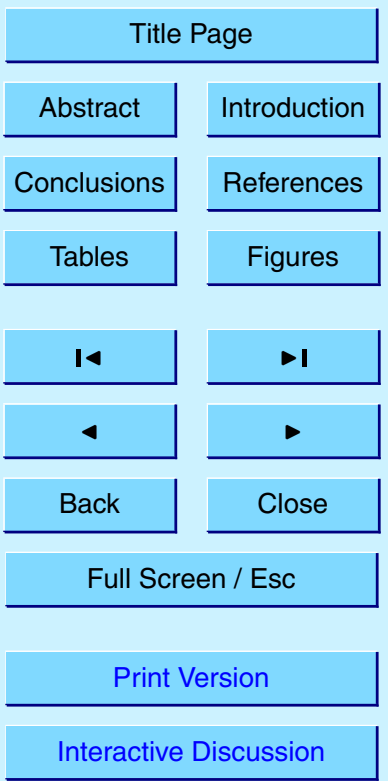

(C) EGU 2003 
Griffin, R. J., Cocker, D. R. I., Seinfeld, J. H., and Dabdub, D.: Estimate of global organic aerosol from oxidation of biogenic hydrocarbons, Geophys. Res. Lett., 26, 2721-2724, 1999b.

Guenther, A., Hewitt, N. C., Erickson, D., Fall, R., Geron, C., Graedel, T., Harley, P., Klinger, L., Lerdau, M., McKay, W. A., Pierce, T., Scholes, B., Steinbrecher, R., Tallamraju, R., Taylor, $5 \quad$ J., and Zimmerman, P.: A global model of natural volatile organic compound emissions, J. Geophys. Res., 100, 8873-8892, 1995.

Hakola, H., Arey, J., Aschmann, S. M., and Atkinson, R.: Product formation from the gas phase reactions of $\mathrm{OH}$ radicals and $\mathrm{O}_{3}$ with a series of monoterpenes, J. Atmos. Chem., 18, 75102, 1994.

10 Hatakeyama, S., Izumi, K., Fukuyama, T., and Akimoto, H.: Reactions of ozone with $\alpha$-pinene and $\beta$-pinene in air: Yields of gaseous and particulate products, J. Geophys. Res., 94, 13013-13024, 1989.

Hatakeyama, S., Izumi, K., Fukuyama, T., Akimoto, H., and Washida, N.: Reactions of OH with alpha-pinene and beta-pinene in air: Estimate of global $\mathrm{CO}$ production from the atmospheric oxidation of terpenes, J. Geophys. Res., 96, 947-958, 1991.

Hoffmann, T., Odum, J., Bowman, F., Collins, D., Klockow, D., Flagan, R. C., and Seinfeld, J. $\mathrm{H}$.: Formation of organic aerosols from the oxidation of biogenic hydrocarbons, J. Atmos. Chem., 26, 189-222, 1997.

Hull, L. A., Terpene ozonolysis products, in: Atmospheric biogenic hydrocarbons, Bufalini, J. J. and Arnts, R. R. (Eds.), 2, 161-184, 1981.

Jang, M. and Kamens, R. M.: Newly characterized products and composition of secondary aerosols from the reaction of $\alpha$-pinene with ozone, Atmos. Environ., 33, 459-474, 1998.

Jaoui, M. and Kamens, R. M.: Mass balance of gaseous and particulate products analysis from $\alpha$-pinene/NO $/$ /air in the presence of natural sunlight, J. Geophys. Res., 106, 12541-12558, 252001.

Jay, K. and Stieglitz, L.: Product analysis of the chemical/photochemical conversion of monoterpenes with airborne pollutants $\left(\mathrm{O}_{3} / \mathrm{NO}_{2}\right)$, in: Air pollution and ecosystems, Mathy, P. (Eds.), 542-547, 1987.

Jenkin, M. E., Shallcross, D. E., and Harvey, J. N.: Development and application of a possi30 ble mechanism for the generation of cis-pinic acid from the ozonolysis of $\alpha$-and $\beta$-pinene, Atmos. Environ., 34, 2837-2850, 2000.

Kanakidou, M., Tsigaridis, K., Dentener, F. J., and Crutzen, P. J.: Human-activity-enhanced formation of organic aerosols by biogenic hydrocarbon oxidation, J. Geophys. Res., 105,

\section{LC-MS analysis of aerosol particles}

R. Winterhalter et al.

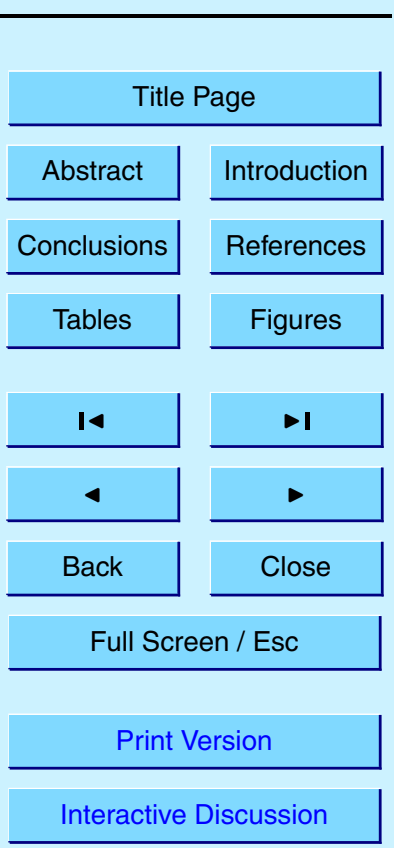


9243-9254, 2000.

Kavouras, I. G., Mihalopoulos, N., and Stephanou, E. G.: Formation of atmospheric particles from organic acids produced by forests, Nature, 395, 683-686, 1998.

Kavouras, I. G., Mihalopoulos, N., and Stephanou, E. G.: Formation and gas/particle partition5 ing of monoterpenes photo-oxidation products over forests, Geophys. Res. Lett., 26, 55-58, 1999a.

Kavouras, I. G., Mihalopoulos, N., and Stephanou, E. G.: Secondary organic aerosol vs primary organic aerosol emission: In situ evidence for the chemical coupling between monoterpene acidic photooxidation products and new particle formation over forests, Environ. Sci. Technol., 3, 1028-1037, 1999b.

Koch, S., Winterhalter, R., Uherek, E., Kolloff, A., Neeb, P., and Moortgat, G. K.: Formation of new particles in the gas-phase ozonolysis of monoterpenes, Atmos. Environ., 34, 40314042, 2000.

Larsen, B. R., Di Bella, D., Glasius, M., Winterhalter, R., Jensen, N. R., and Hjorth, J.: Gas15 phase $\mathrm{OH}$ oxidation of monoterpenes: Gaseous and particulate products, J. Atmos. Chem., 38, 231-276, 2001.

Larsen, B. R., Lahaniati, M., Calogirou, A., and Kotzias, D.: Atmospheric oxidation products of terpenes - a new nomenclature, Chemosphere, 37, 1207-1220, 1998.

Mäkelä, J. M., Aalto, P., Jokinen, V., Phoja, T., Nissinen, A., Palmroth, S., Markkanen, T., Seitsonen, K., Lihavainen, H., and Kulmala, M.: Observations of ultrafine aerosol particle formation and growth in boreal forest, Geophys. Res. Lett., 24, 1219-1222, 1997.

Martinez, R. I., Herron, J. T., and Huie, R. E.: The mechanism of ozone-alkene reactions in the gas phase. A mass spectrometric study of the reactions of eight linear and branched-chain alkenes., J. Am. Chem. Soc., 103, 3807-3820, 1981.

Niki, H., Maker, P. D., Savage, C. M., Breitenbach, L. P., and Hurley, M. D.: FTIR spectroscopic study of the mechanism for the gas-phase reaction between ozone and tetramethylethylene., J. Phys. Chem., 91, 941-946, 1987.

Odum, J. R., Hoffmann, T., Bowman, F., Collins, D., Flagan, R. C., and Seinfeld, J. H.: Gas/particle partitioning and secondary organic aerosol formation, Environ. Sci. Technol., $30 \quad 30,2580-2585,1996$.

Paulson, S. E., Sen, A. D., Liu, P., Fenske, J. D., and Fox, M. J.: Evidence for formation of $\mathrm{OH}$ radicals from the reaction of $\mathrm{O}_{3}$ with alkenes in the gas phase, Geophys. Res. Lett., 24, 3193-3196, 1997.
ACPD

3, 1-39, 2003

LC-MS analysis of aerosol particles

R. Winterhalter et al.

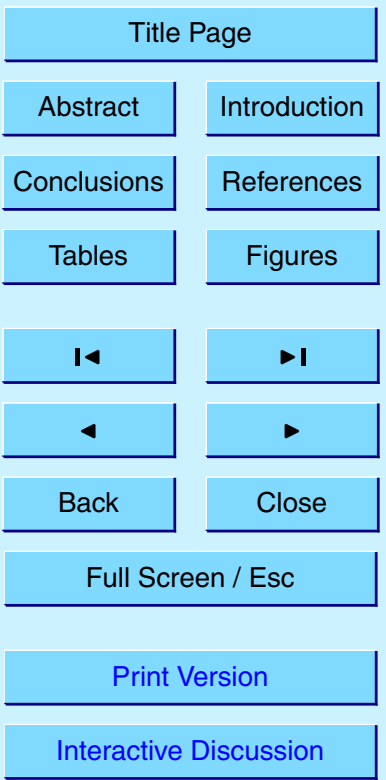

(C) EGU 2003 
Peeters, J., Vereecken, L., and Fantechi, G.: The detailed mechanism of the OH-initiated atmospheric oxidation of $\alpha$-pinene: a theoretical study, Phys. Chem. Chem. Phys., 3, 5489-5504, 2001.

Pio, C. A., Alves, C. A., and Duarte, A. C.: Identification, abundance and origin of atmospheric organic particulate matter in a Portugese rural area, Atmos. Environ., 35, 1365-1375, $2001 \mathrm{a}$.

Pio, C. A., Alves, C. A., and Duarte, A. C.: Organic components of aerosols in a forested area of central Greece, Atmos. Environ., 35, 389-401, 2001b.

Vereecken, L. and Peeters, J.: Theoretical study of the formation of acetone in the $\mathrm{OH}$-initiated atmospheric oxidation of $\alpha$-pinene, J. Phys. Chem. A, 104, 11140-11146, 2000.

10 Vinckier, C., Compernolle, F., Saleh, A. M., Van Hoof, N., and Van Hees, I.: Product yields of the alpha-pinene reaction with hydroxyl radicals and the implication on the global emission of trace compounds in the atmosphere, Fresenius Environmental Bulletin, 7, 361-368, 1998.

Wadt, W. R. and Goddard, W. A.: The electronic structure of the Criegee intermediate. Ramifications for the mechanism of ozonolysis, J. Am. Chem. Soc., 97, 3004-3021, 1975.

15 Went, F. W.: Blue hazes in the atmosphere, Nature, 187, 641-643, 1960.

Winterhalter, R., Neeb, P., Grossmann, D., Kolloff, A., Horie, O., and Moortgat, G. K.: Products and mechanism of the gas phase reaction of ozone with $\beta$-pinene, J. Atmos. Chem., 35, 165-197, 2000.

Wisthaler, A., Jensen, N. R., Winterhalter, R., Lindinger, W., and Hjorth, J.: Measurements of acetone and other gas phase product yields from the $\mathrm{OH}$-initiated oxidation of terpenes by proton-transfer-reaction mass spectrometry (PTR-MS), Atmos. Environ., 35, 6181-6191, 2001.

Yu, J., Cocker, D. R. I., Griffin, R. J., Flagan, R. C., and Seinfeld, J. H.: Gas-Phase Ozone Oxidation of Monoterpenes: Gaseous and Particulate Products, J. Atmos. Chem., 34, 207258, 1999.

ACPD

3, 1-39, 2003

\section{LC-MS analysis of aerosol particles}

R. Winterhalter et al.

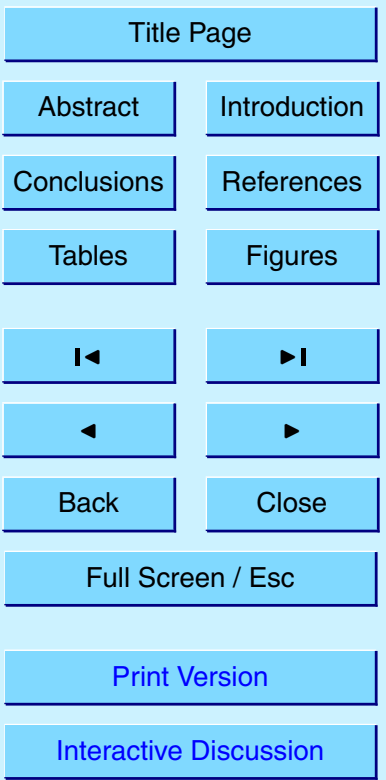

(C) EGU 2003 
ACPD

3, 1-39, 2003

Table 1. Experimental conditions for the $\alpha$-pinene oxidation experiments

\begin{tabular}{ccccccl}
\hline Experiment & $\begin{array}{c}\alpha \text {-pinene } \\
{[\mathrm{ppb}]}\end{array}$ & $\begin{array}{c}\mathrm{NO}_{\mathrm{x}} \\
{[\mathrm{ppb}]}\end{array}$ & $\mathrm{O}_{3}[\mathrm{ppb}]$ & $\begin{array}{c}\text { Relative } \\
\text { humidity }\end{array}$ & $\begin{array}{c}\text { Seed } \\
\text { aerosol }\end{array}$ & Type of experiment \\
\hline 2609A & 50 & 14 & & dry & yes & Photosmog experiment \\
2709A & 100 & 11 & & dry & yes & Photosmog experiment \\
2809A & 100 & $<2$ & & dry & yes & low $\mathrm{NO}_{\mathrm{x}}, \mathrm{HCHO}$-photolysis \\
2909A & 100 & 15 & & $46 \%$ & yes & Photosmog experiment \\
3009A & 100 & 8 & & $46 \%$ & yes & Photosmog experiment \\
0210A & 100 & - & 130 & dry & no & 1 1) Ozonolysis 2) Ageing \\
0310A & 100 & - & - & & yes & Photolysis of 20 ppm $\mathrm{H}_{2} \mathrm{O}_{2}$ \\
0410A & 100 & - & 140 & dry & no & 1 1) Ozonolysis 2) Ageing \\
0510A & 100 & - & 140 & $45 \%$ & no & 1 ) Ozonolysis 2) Ageing \\
2609B & 50 & 3 & & dry & yes & constant $\mathrm{NO}_{\mathrm{x}}$ \\
2709B & 100 & 3 & & dry & yes & constant $\mathrm{NO}_{\mathrm{x}}$ \\
2809B & 100 & $<2$ & & dry & yes & low $\mathrm{NO}_{\mathrm{x}}, \mathrm{HCHO}$-photolysis \\
2909B & 100 & 3 & & $49 \%$ & yes & constant $\mathrm{NO}_{\mathrm{x}}$ \\
3009B & 100 & 5 & & $49 \%$ & yes & constant $\mathrm{NO}_{\mathrm{x}}$ \\
\hline
\end{tabular}

\section{LC-MS analysis of} aerosol particles

R. Winterhalter et al.

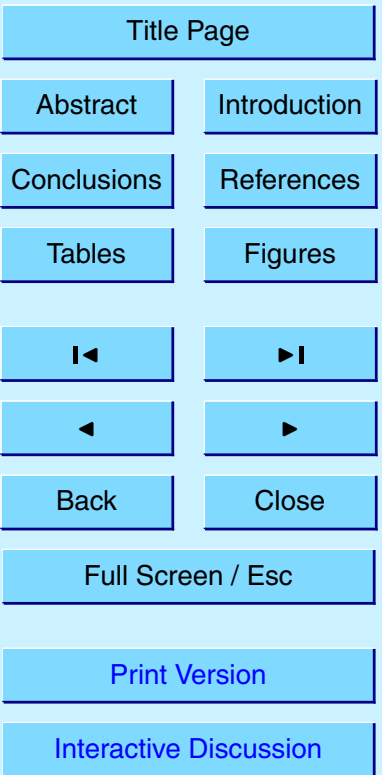

(C) EGU 2003 
Table 2. (a) Observed ions and assigned products from LC-MS analysis of $\alpha$-pinene oxidation products. Structures and IUPAC names are shown in Table $2 b$

\begin{tabular}{|c|c|c|c|c|}
\hline $\mathbf{M}_{\mathbf{W}}$ & $\begin{array}{l}\text { Retention } \\
\text { time (min) }\end{array}$ & ESI(-) & $\mathrm{APCI}(+)$ & $\begin{array}{l}\text { possible structures of detected products } \\
\text { bold: confirmed by authentic sample }\end{array}$ \\
\hline 168 & $\begin{array}{l}6.00 \\
7.23\end{array}$ & - & $\begin{array}{l}169 \\
169\end{array}$ & $\begin{array}{l}\text { 2-hydroxy-3-pinanone 1, 8-hydroxy-menthen-6-one } 2 \\
\text { Pinonaldehyde } 3\end{array}$ \\
\hline 170 & $\begin{array}{l}5.38 \\
6.00 \\
6.75\end{array}$ & $\begin{array}{l}169+229 \\
169+229 \\
169+229\end{array}$ & $\begin{array}{l}171 \\
171 \\
171\end{array}$ & Pinalic acid 4, 5, Norpinonic acid 6 \\
\hline 172 & $\begin{array}{l}2.45 \\
4.59 \\
5.51\end{array}$ & $\begin{array}{l}171+231 \\
171+231 \\
171+231\end{array}$ & $\begin{array}{c}173 \\
- \\
-\end{array}$ & $\begin{array}{l}M_{w} 172 \text { ("pinolic acid") } 7 \\
\text { Norpinic acid } 8\end{array}$ \\
\hline 182 & $\begin{array}{l}3.38 \\
5.82 \\
9.36\end{array}$ & $\begin{array}{l}- \\
-\end{array}$ & $\begin{array}{l}183 \\
183 \\
183\end{array}$ & Keto-pinonaldehyde $\mathbf{9 , 1 0}$ \\
\hline 184 & $\begin{array}{l}5.35 \\
5.82 \\
9.50 \\
7.11\end{array}$ & $\begin{array}{c}- \\
- \\
- \\
183+243\end{array}$ & $\begin{array}{l}185 \\
185 \\
185 \\
185\end{array}$ & $\begin{array}{l}\text { OH-Pinonaldehyde 11, 12, } 13 \\
\text { 3-Acetyl-5,6-dioxo-heptanal } 14 \\
\text { Esters 15, 16, } 17 \\
\text { Pinonic acid } 18\end{array}$ \\
\hline 186 & $\begin{array}{l}4.75 \\
5.75 \\
5.83\end{array}$ & $\begin{array}{c}- \\
185 \\
-\end{array}$ & $\begin{array}{c}187 \\
- \\
187\end{array}$ & $\begin{array}{l}\beta \text {-hydroxy-hydroperoxyde 19, } 20 \\
\text { Pinic acid } 21 \\
\text { Pinalic-peroxo acid } 22\end{array}$ \\
\hline 188 & $\begin{array}{l}5.50 \\
6.00\end{array}$ & $\begin{array}{l}187+247 \\
187+247\end{array}$ & - & $\begin{array}{l}? \\
?\end{array}$ \\
\hline 198 & $\begin{array}{c}6.10 \\
9.99 \\
11.00\end{array}$ & $\begin{array}{c}197+257 \\
- \\
197+257\end{array}$ & $\begin{array}{c}199 \\
199 \\
-\end{array}$ & Keto-pinonic acid 23, 24 \\
\hline 200 & $\begin{array}{l}3.53 \\
5.83 \\
9.40\end{array}$ & $\begin{array}{c}199+259 \\
- \\
199+259\end{array}$ & $\begin{array}{c}- \\
201 \\
201\end{array}$ & $\begin{array}{l}\text { OH-Pinonic acid 26, 27, } 28 \\
\text { Hydroperoxy-pinonaldehyde 29, Aldehyde } 25\end{array}$ \\
\hline 202 & 5.93 & $201+261$ & - & Peroxo-pinic acid $\mathbf{3 0}$ \\
\hline
\end{tabular}

\section{ACPD}

3, 1-39, 2003

\section{LC-MS analysis of aerosol particles}

R. Winterhalter et al.

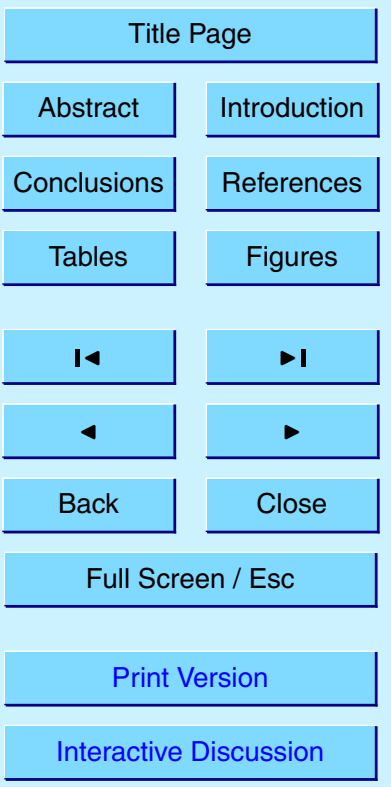

(C) EGU 2003 
Table 2. (b) Structures and IUPAC names of $\alpha$-pinene oxidation products

\begin{tabular}{|c|c|c|c|c|}
\hline 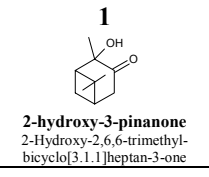 & <- & 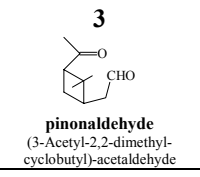 & $\begin{array}{c}\text { pinalic acid } \\
\text { 2,2-Dimethyl-3-(2-oxo-ethyl)- } \\
\text { cyclobutane-carboxylic acid }\end{array}$ & $\underbrace{\mathbf{5}}_{\substack{\text { pinalic acid } \\
\text { (3-Formyl-2,2-dimethyl- } \\
\text { cyclobutyl)-acetic acid }}}$ \\
\hline 6 & 7 & 8 & 9 & 10 \\
\hline $\begin{array}{c}\text { norpinonic acid } \\
\text { 3-Acetyl-2,2-dimethyl- } \\
\text { cyclobutanecarboxylic acid }\end{array}$ & $\begin{array}{c}\mathbf{M}_{\mathbf{w}} \mathbf{1 7 2} \text { "pinolic acid" } \\
\text { 3-(2-Hydroxy-ethyl)-2,2- } \\
\text { dimethyl-cyclobutane- } \\
\text { carboxylic acid }\end{array}$ & $\begin{array}{l}\text { norpinic acid } \\
\text { 2,2-Dimethyl-cyclobutane-1,3- } \\
\text { dicarboxylic acid }\end{array}$ & $\begin{array}{l}\text { 10-keto-pinonaldehyde } \\
\text { (3-Acetyl-3-oxo-2,2-dimethyl- } \\
\text { cyclobutyl)-acetaldehyde }\end{array}$ & $\begin{array}{l}\text { 4-keto-pinonaldehyde } \\
\text { (3-Acetyl-2,2-dimethlyl- } \\
\text { cyclobutyl)-2-oxo-acetaldehyde }\end{array}$ \\
\hline 11 & 12 & 13 & 14 & 15 \\
\hline 10-OH-pinonaldehyde & 1-OH-pinonaldehyde & 4-OH-pinonaldehyde & & pinalic acid methyl ester \\
\hline $\begin{array}{l}\text { [3-(2-Hydroxy-ethanoyl)-2,2- } \\
\text { dimethyl-cyclobutyl]- } \\
\text { acetaldehyde }\end{array}$ & $\begin{array}{c}\text { (3-Acetyl-3-hydroxy-2,2- } \\
\text { dimethyl-cyclobutyl)- } \\
\text { acetaldehyde }\end{array}$ & $\begin{array}{l}\text { (3-Acetyl-2,2-dimethyl- } \\
\text { cyclobutyl)-2-hydroxy- } \\
\text { acetaldehyde }\end{array}$ & 3-Acetyl-5,6-dioxo-heptanal & $\begin{array}{c}\text { 2,2-Dimethyl-3-(2-oxo-ethyl)- } \\
\text { cyclobutanecarboxylic acid } \\
\text { methyl ester }\end{array}$ \\
\hline 16 & 17 & 18 & 19 & 20 \\
\hline $\begin{array}{l}\text { Acetic acid 2,2-dimethyl-3-(2- } \\
\text { oxo-ethyl)-cyclobutyl ester }\end{array}$ & $\begin{array}{l}\text { Formic acid 3-acetyl-2,2- } \\
\text { dimethyl-cyclobutyl ester }\end{array}$ & $\begin{array}{c}\text { pinonic acid } \\
\text { (3-Acetyl-2,2-dimethyl- } \\
\text { cyclobutyl)-acetic acid }\end{array}$ & 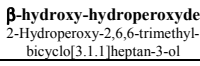 & $\begin{array}{l}\text { 及-hydroxy-hydroperoxyde } \\
\text { 3-Hydroperoxy-2,6,6-trimethyl- } \\
\text { bicyclo[3.1.1] heptan-2-ol }\end{array}$ \\
\hline 21 & 22 & 23 & 24 & 25 \\
\hline $\begin{array}{c}\text { pinic acid } \\
\text { 3-Carboxymethyl-2,2-dimethyl- } \\
\text { cyclobutane-carboxylic acid }\end{array}$ & $\begin{array}{l}\text { pinalic-peroxo acid } \\
\text { 2,2-Dimethyl-3-(2-oxo-ethyl)- } \\
\text { cyclobutane-carboperoxoic acid }\end{array}$ & $\begin{array}{l}\text { 7-keto-pinonic acid } \\
\text { [2,2-Dimethyl-3-(2-oxo- } \\
\text { ethanoyl)-cyclobutyl]-acetic } \\
\text { acid }\end{array}$ & $\begin{array}{l}\text { 4-keto-pinonic acid } \\
\text { (3-Acetyl-2,2-dimethyl- } \\
\text { cyclobutyl)-2-oxo-acetic acid }\end{array}$ & $\begin{array}{l}\text { 3-(1-Hydroxy-1-methyl-ethyl)- } \\
\text { 5,6-dioxo-heptanal }\end{array}$ \\
\hline 26 & 27 & 28 & 29 & 30 \\
\hline 10-OH-pinonic acid & 1-OH-pinonic acid & 4-OH-pinonic acid & $\begin{array}{l}\text { 4-hydroperoxy- } \\
\text { pinonaldehyde }\end{array}$ & peroxo-pinic acid \\
\hline $\begin{array}{l}\text { [3-(2-Hydroxy-ethanoyl)-2,2- } \\
\text { dimethyl-cyclobutyl]-acetic } \\
\text { acid }\end{array}$ & $\begin{array}{l}\text { (3-Acetyl-3-hydroxy-2,2- } \\
\text { dimethyl-cyclobutyl)-acetic } \\
\text { acid }\end{array}$ & $\begin{array}{l}\text { (3-Acetyl-2,2-dimethyl- } \\
\text { cyclobutyl)-2-hydroxy-acetic } \\
\text { acid }\end{array}$ & $\begin{array}{l}\text { (3-Acetyl-2,2-dimethyl- } \\
\text { cyclobutyl)-2-hydroper-oxy- } \\
\text { acetaldehyde }\end{array}$ & $\begin{array}{l}\text { 3-Hydroperoxycarbonyl- } \\
\text { methyl-2,2-dimethyl-cyc- } \\
\text { lobutane-carboxylic acid }\end{array}$ \\
\hline
\end{tabular}

\section{ACPD}

3, 1-39, 2003

\section{LC-MS analysis of} aerosol particles

R. Winterhalter et al.

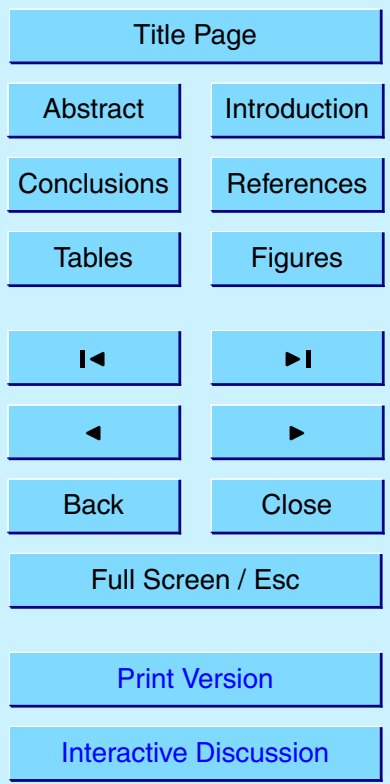

(C) EGU 2003 
ACPD

3, 1-39, 2003

Table 3. Molar yields (in \%) of particulate products from $\alpha$-pinene-ozonolysis experiments

\begin{tabular}{|c|c|c|c|c|}
\hline & 0210A & 0410A & 0510A & Average $^{d}$ \\
\hline$[\alpha \text {-pinene }]_{\text {reacted }}[\mathrm{ppb}]$ & 71 & 56 & 59 & \\
\hline pinic acid & 1.79 & 1.25 & 1.62 & $1.55 \pm 0.28$ \\
\hline pinonic acid & 0.89 & 0.79 & 0.44 & $0.71 \pm 0.24$ \\
\hline OH-pinonic acid ${ }^{\mathrm{a}}$ & 0.70 & 0.50 & 0.34 & $0.51 \pm 0.18$ \\
\hline keto-pinonic acid ${ }^{\text {a }}$ & 0.14 & 0.19 & 0.14 & $0.16 \pm 0.03$ \\
\hline $\mathrm{M}_{\mathrm{w}} 170^{\mathrm{b}}$ & 0.25 & 0.51 & 0.34 & $0.37 \pm 0.13$ \\
\hline norpinic acid & 0.08 & 0.06 & 0.05 & $0.06 \pm 0.02$ \\
\hline $\mathrm{M}_{\mathrm{w}} 172$ & 0.90 & 1.24 & 0.83 & $0.99 \pm 0.22$ \\
\hline $\mathrm{M}_{\mathrm{w}} 186^{\mathrm{a}}$ & 0.20 & 0.13 & 0.07 & $0.13 \pm 0.07$ \\
\hline $\mathrm{M}_{\mathrm{w}} 188^{\mathrm{a}}$ & 0.18 & 0.16 & 0.15 & $0.16 \pm 0.02$ \\
\hline pinonaldehyde & 0.35 & 0.18 & 0.33 & $0.29 \pm 0.09$ \\
\hline OH-pinonaldehyde ${ }^{\text {a }}$ & 0.13 & 0.08 & 0.09 & $0.10 \pm 0.03$ \\
\hline keto-pinonaldehyde $^{\text {a }}$ & 0.13 & 0.04 & 0.05 & $0.07 \pm 0.05$ \\
\hline $\mathrm{M}_{\mathrm{w}} 200$ & 0.13 & 0.03 & 0.04 & $0.07 \pm 0.06$ \\
\hline sum of other compounds ${ }^{c}$ & 0.23 & 0.17 & 0.13 & $0.18 \pm 0.05$ \\
\hline carbon mass balance (\%) & 5.77 & 5.00 & 4.32 & 5.03 \\
\hline sum of yields (\%) & 6.10 & 5.33 & 4.62 & $5.35 \pm 0.74$ \\
\hline aerosol mass yield (\%) & $15.3-19.7$ & $14.6-15.7$ & $13.4-15.6$ & $15.72 \pm 2.13$ \\
\hline
\end{tabular}

\section{LC-MS analysis of aerosol particles}

R. Winterhalter et al.

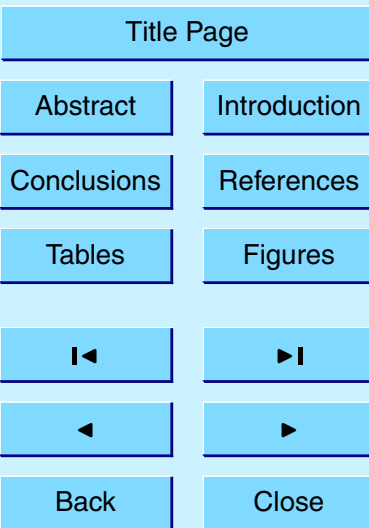

Full Screen / Esc

Print Version

Interactive Discussion

C) EGU 2003 
ACPD

3, 1-39, 2003

Table 4. Comparison of molar yields (in \%) of particulate products from $\alpha$-pinene-ozonolysis

\begin{tabular}{|c|c|c|c|c|}
\hline & $\begin{array}{c}\text { Yu et al. } \\
1999\end{array}$ & $\begin{array}{l}\text { Glasius et al. } \\
2000\end{array}$ & $\begin{array}{c}\text { Koch et al. } \\
2000\end{array}$ & $\begin{array}{c}\text { This study } \\
\text { (3 experiments) }\end{array}$ \\
\hline OH-scavenger & 2-butanol & cyclohexane & cyclohexane & - \\
\hline seed aerosol & $\left(\mathrm{NH}_{4}\right)_{2} \mathrm{SO}_{4}$ & - & - & - \\
\hline$[\alpha \text {-pinene }]_{0}[\mathrm{ppb}]$ & $50-110$ & 1800 & 5000 & 100 \\
\hline pinic acid & $1.8-3.9$ & 1.4 & 3.2 & $1.55 \pm 0.28$ \\
\hline pinonic acid & $1.3-1.7$ & 1.5 & 1.2 & $0.71 \pm 0.24$ \\
\hline OH-pinonic acid ${ }^{\text {a }}$ & $1.3-2.1$ & 0.86 & & $0.51 \pm 0.18$ \\
\hline keto-pinonic acid ${ }^{\mathrm{a}}$ & $0.48-0.80$ & & & $0.16 \pm 0.03$ \\
\hline $\mathrm{M}_{\mathrm{w}} 170^{\mathrm{b}}$ & $2.1-4.8$ & 0.19 & & $0.37 \pm 0.13$ \\
\hline norpinic acid & $0.05-0.09$ & 0.04 & & $0.06 \pm 0.02$ \\
\hline Mw 172 & & & & $0.99 \pm 0.22$ \\
\hline $\operatorname{Mw} 186^{\mathrm{a}}$ & & & & $0.13 \pm 0.07$ \\
\hline Mw $188^{a}$ & & & & $0.16 \pm 0.02$ \\
\hline pinonaldehyde & $0.3-0.9$ & 1.9 & & $0.29 \pm 0.09$ \\
\hline OH-pinonaldehyde ${ }^{\text {a }}$ & $1.1-2.4$ & 0.32 & & $0.10 \pm 0.03$ \\
\hline keto-pinonaldehyde $^{\text {a }}$ & & & & $0.07 \pm 0.05$ \\
\hline Mw 200 & & & & $0.07 \pm 0.06$ \\
\hline sum of other compounds & $0.18-0.32$ & & $<2.0$ & $0.18 \pm 0.05$ \\
\hline carbon mass balance (\%) & $11.3-12.9$ & 6.15 & 5.88 & $5.03 \pm 0.72$ \\
\hline sum of yields (\%) & $11.7-13.9$ & 6.21 & 4.4 & $5.35 \pm 0.74$ \\
\hline aerosol mass yield (\%) & $15.9-17.6$ & - & - & $15.72 \pm 2.13$ \\
\hline
\end{tabular}

\section{LC-MS analysis of aerosol particles}

R. Winterhalter et al.

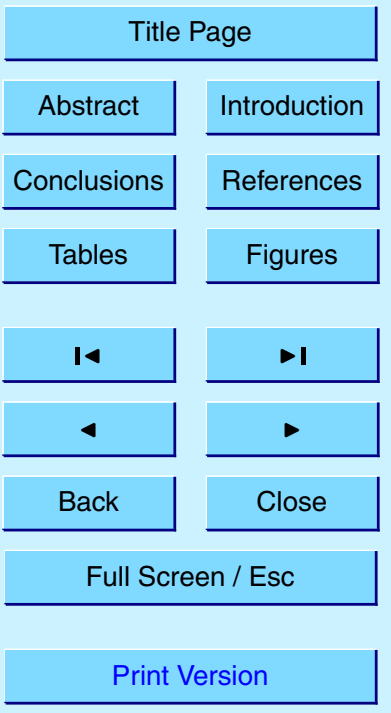

Interactive Discussion

C) EGU 2003 
ACPD

3, 1-39, 2003

Table 5. Molar yields (in \%) of particulate products from $\alpha$-pinene photosmog experiments

\begin{tabular}{|c|c|c|c|c|c|}
\hline & 2709A & 2909A & 2709B & 2809B & Average $^{\mathrm{c}}$ \\
\hline$[\alpha \text {-pinene }]_{\text {reacted }}[\mathrm{ppb}]$ & 77 & 70 & 74 & 55 & \\
\hline pinic acid & 0.24 & 0.37 & 0.26 & 0.23 & $0.28 \pm 0.07$ \\
\hline pinonic acid & 0.14 & 0.07 & 0.20 & 0.23 & $0.16 \pm 0.07$ \\
\hline OH-pinonic acid ${ }^{\mathrm{a}}$ & 0.09 & 0.12 & 0.11 & 0.08 & $0.10 \pm 0.02$ \\
\hline keto-pinonic acid ${ }^{\text {a }}$ & 0.01 & 0.01 & 0.02 & 0.01 & $0.013 \pm 0.07$ \\
\hline $\mathrm{M}_{\mathrm{w}} 170^{\mathrm{b}}$ & 0.03 & 0.05 & 0.06 & 0.19 & $0.08 \pm 0.07$ \\
\hline norpinic acid & 0.04 & 0.12 & 0.04 & 0.02 & $0.06 \pm 0.04$ \\
\hline $\mathrm{M}_{\mathrm{W}} 172$ & 0.36 & 0.21 & 0.23 & 0.22 & $0.26 \pm 0.07$ \\
\hline $\mathrm{M}_{\mathrm{w}} 186^{\mathrm{a}}$ & 0.03 & 0.02 & 0.04 & 0.02 & $0.03 \pm 0.01$ \\
\hline $\mathrm{M}_{\mathrm{w}} 188^{\mathrm{a}}$ & 0.07 & 0.06 & 0.06 & 0.09 & $0.07 \pm 0.01$ \\
\hline pinonaldehyde & 0.04 & 0.04 & 0.07 & 0.13 & $0.07 \pm 0.04$ \\
\hline OH-pinonaldehyde ${ }^{\text {a }}$ & 0.01 & - & 0.02 & 0.03 & $0.02 \pm 0.01$ \\
\hline keto-pinonaldehyde ${ }^{a}$ & 0.01 & - & - & 0.02 & $0.015 \pm 0.007$ \\
\hline $\mathrm{M}_{\mathrm{w}} 200$ & - & - & - & - & - \\
\hline carbon mass balance (\%) & 1.00 & 0.98 & 1.05 & 1.20 & $1.07 \pm 0.10$ \\
\hline sum of yields (\%) & 1.07 & 1.07 & 1.11 & 1.27 & $1.14 \pm 0.10$ \\
\hline aerosol mass yield (\%) & 3.8 & 3.5 & 8.8 & 10.0 & \\
\hline
\end{tabular}

\section{LC-MS analysis of aerosol particles}

R. Winterhalter et al.

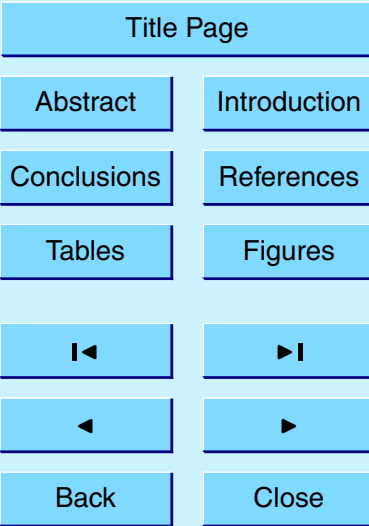

Full Screen / Esc

Print Version

Interactive Discussion

C) EGU 2003 
ACPD

3, 1-39, 2003

Table 6. Molar yields (in \%) of particulate products from $\mathrm{OH} / \alpha$-pinene reaction using $\mathrm{H}_{2} \mathrm{O}_{2}$ as $\mathrm{OH}$-radical source

\begin{tabular}{ccc}
\hline & Larsen et al. 2001 & this study \\
\hline seed aerosol & - & $\left(\mathrm{NH}_{4}\right)_{2} \mathrm{SO}_{4}$ \\
{$[\alpha \text {-pinene }]_{0}[\mathrm{ppb}]$} & $1400-1600$ & 100 \\
\hline pinic acid & 0.03 & 0.23 \\
pinonic acid & 0.44 & 0.17 \\
OH-pinonic acid & 0.14 & 0.05 \\
morpinonic, pinalic acid $\left(\mathrm{M}_{\mathrm{w}}\right.$ 170) & 0.11 & 0.23 \\
norpinic acid & 0.02 & 0.04 \\
Mw 172 & 0.07 & 0.26 \\
Mw 216 & 0.09 & \\
Mw 186 & & 0.03 \\
Mw 188 & & 0.17 \\
pinonaldehyde & 0.8 & 0.09 \\
OH-pinonaldehyde & 0.1 & 0.02 \\
keto-pinonaldehyde & & 0.07 \\
\hline carbon mass balance $(\%)$ & 1.78 & 1.2 \\
sum of yields $(\%)$ & 1.79 & 1.39 \\
aerosol mass yield $(\%)$ & - & 7.0 \\
\hline
\end{tabular}

\section{LC-MS analysis of aerosol particles}

R. Winterhalter et al.

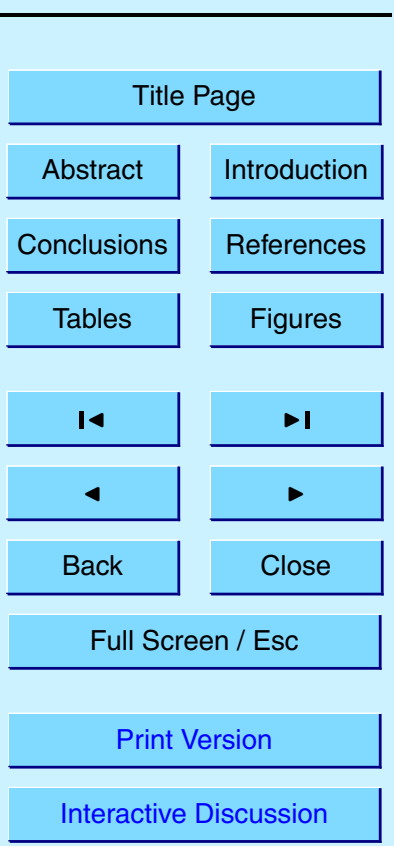

(C) EGU 2003 


\section{ACPD}

3, 1-39, 2003

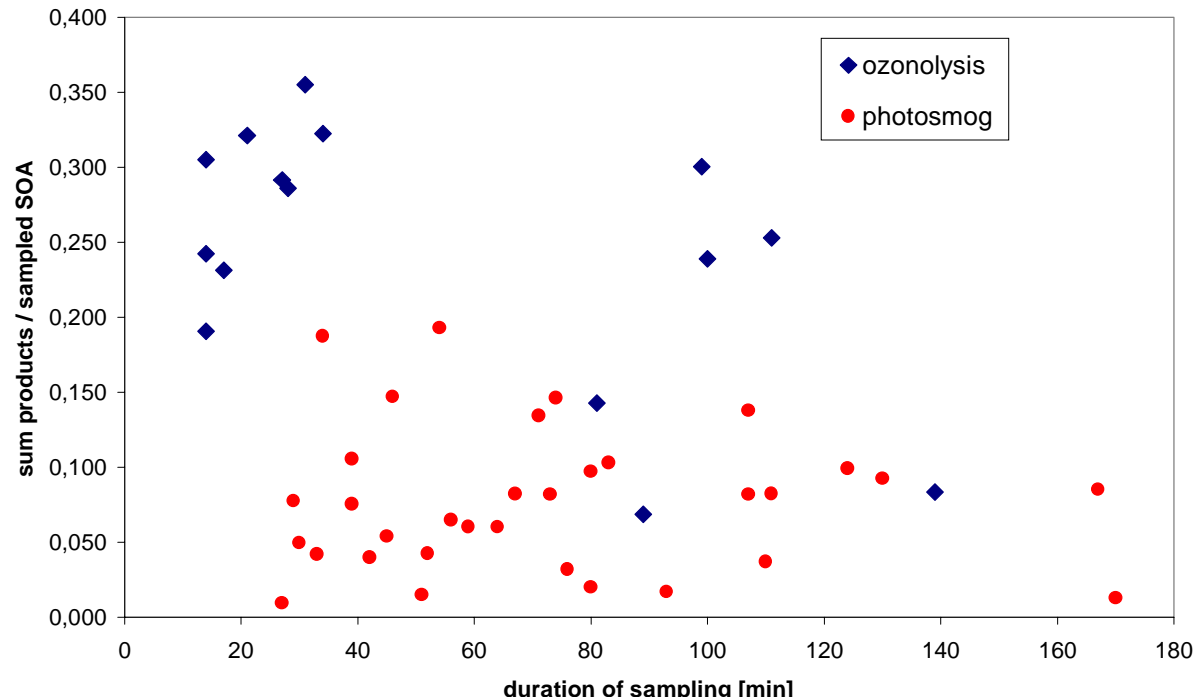

Fig. 1. Effect of duration of filter sampling on obtained mass balances. Mass balance is the ratio of identified products $[\mu \mathrm{g}]$, i.e. product concentration $\times$ sampled volume, to theoretically sampled SOA $[\mu \mathrm{g}]$, SOA mass concentration $\times$ sampled volume, assuming a density of $1 \mathrm{~g} / \mathrm{cm}^{3}$ for the organic particles.

\section{LC-MS analysis of aerosol particles}

R. Winterhalter et al.

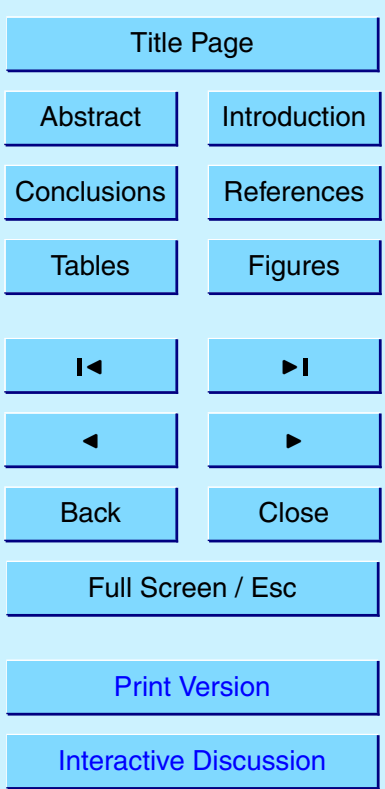

(C) EGU 2003 


\section{ACPD}

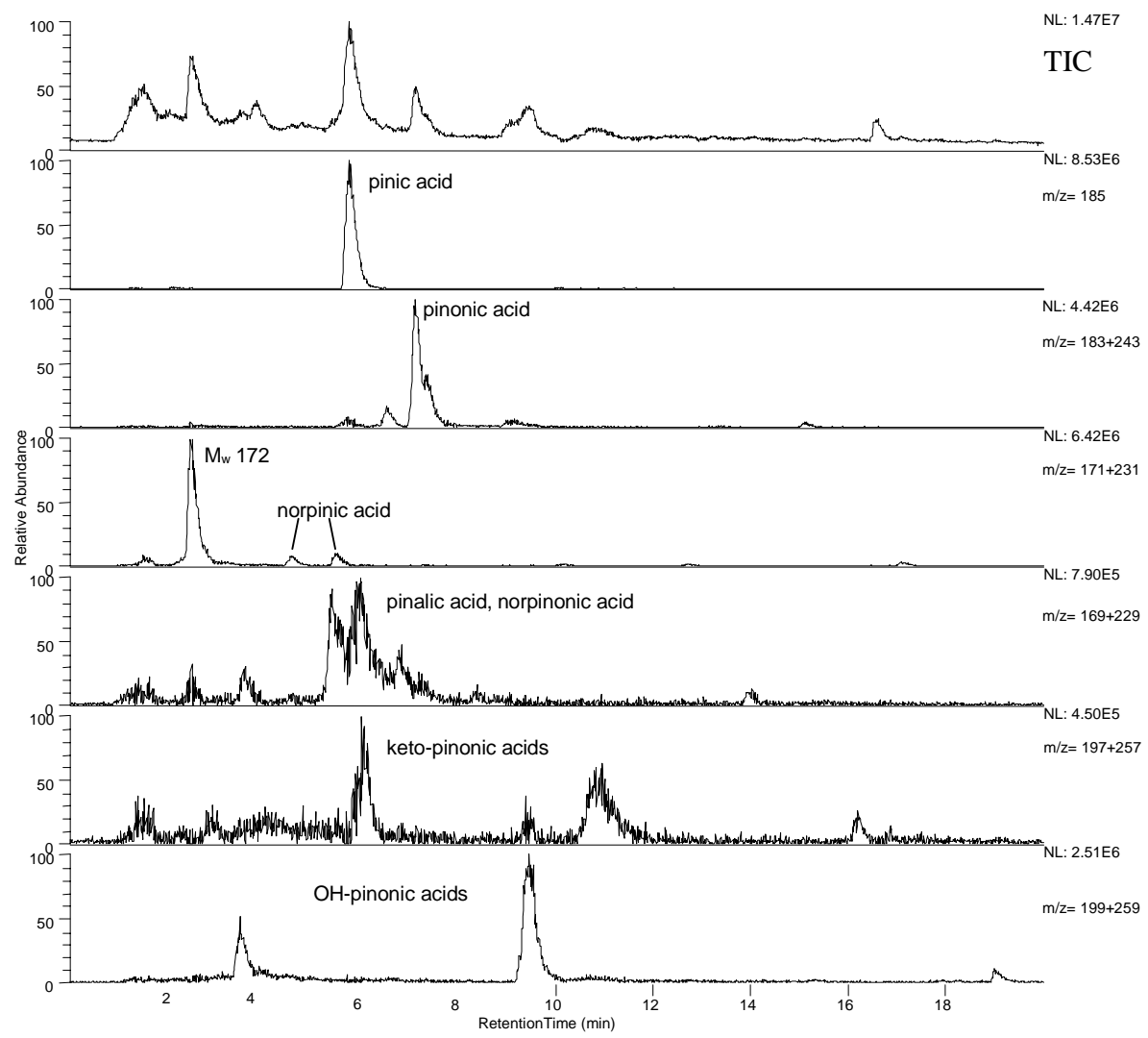

3, 1-39, 2003

\section{LC-MS analysis of aerosol particles}

R. Winterhalter et al.

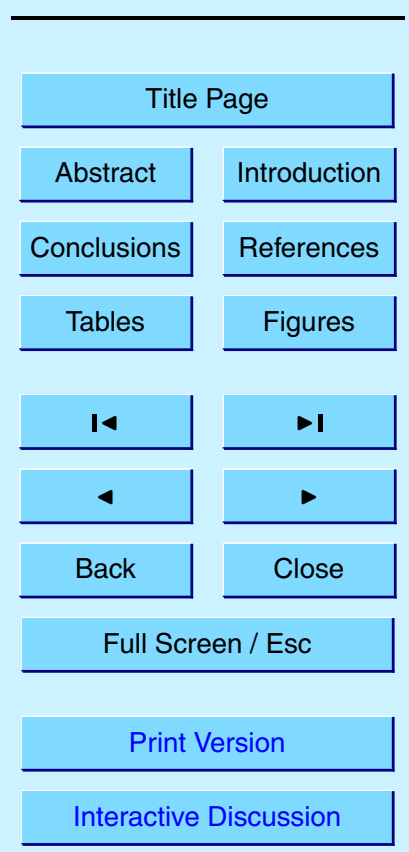

Fig. 2. Total ion chromatogram (TIC) and extracted ion chromatograms of a sample from $\alpha$ pinene-ozonolysis analysed in the ESI(-) mode.

(C) EGU 2003 


\section{ACPD}

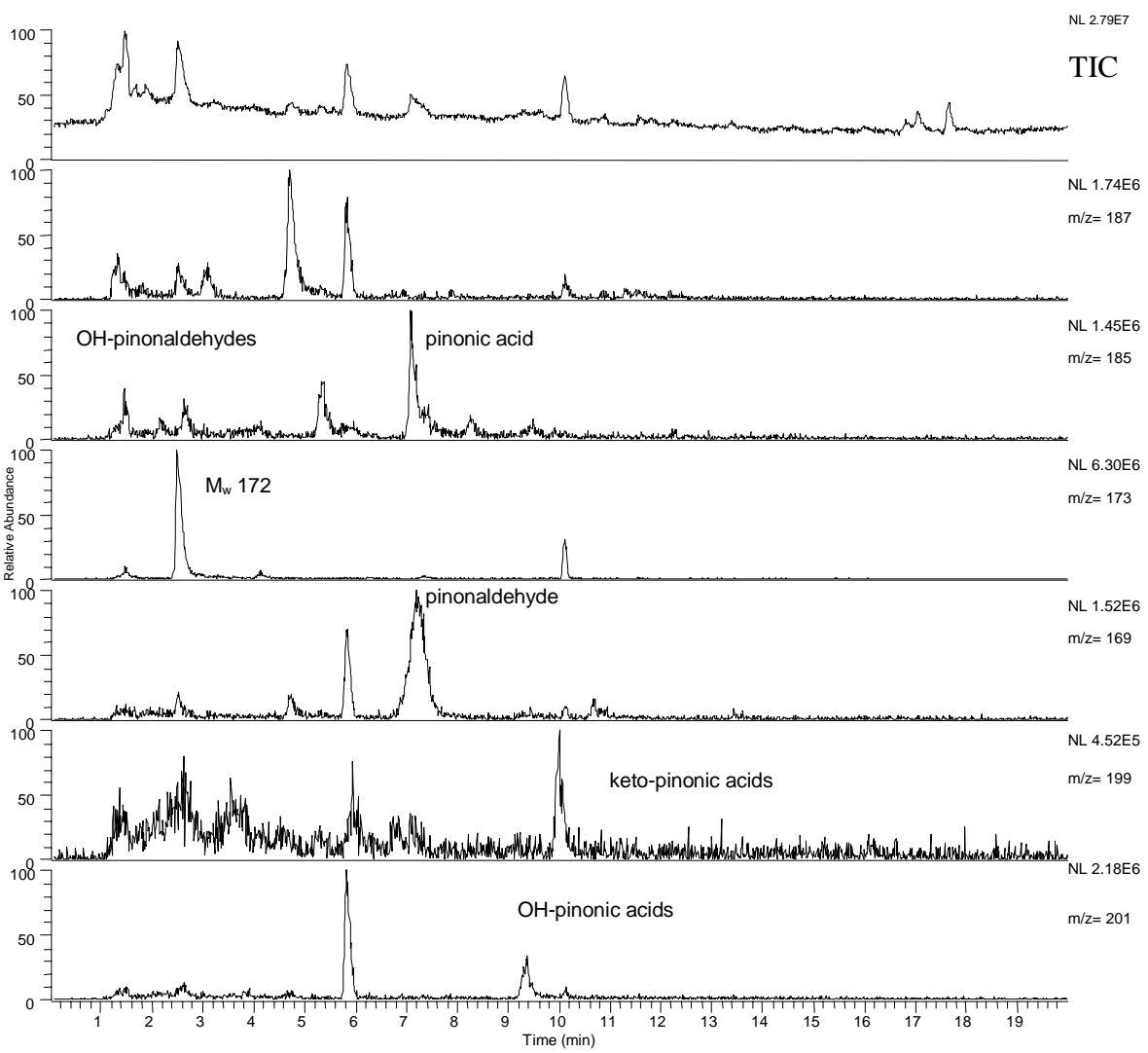

3, 1-39, 2003

\section{LC-MS analysis of aerosol particles}

R. Winterhalter et al.

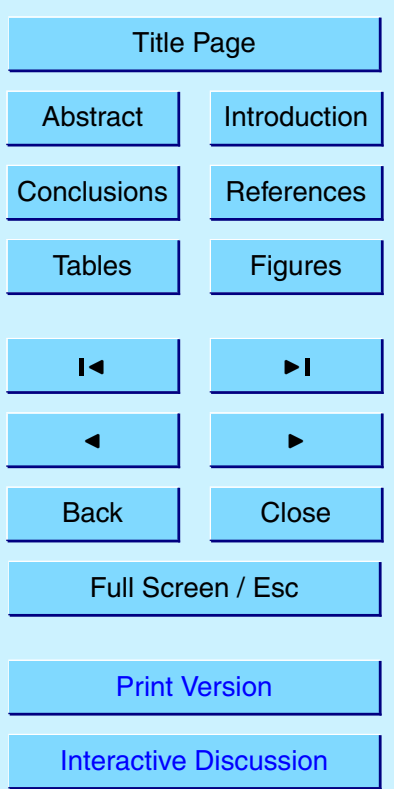

Fig. 3. TIC and extracted ion chromatogram of a sample from $\alpha$-pinene-ozonolysis analysed in the $\mathrm{APCl}(+)$ mode.

(C) EGU 2003 


\section{ACPD}

3, 1-39, 2003

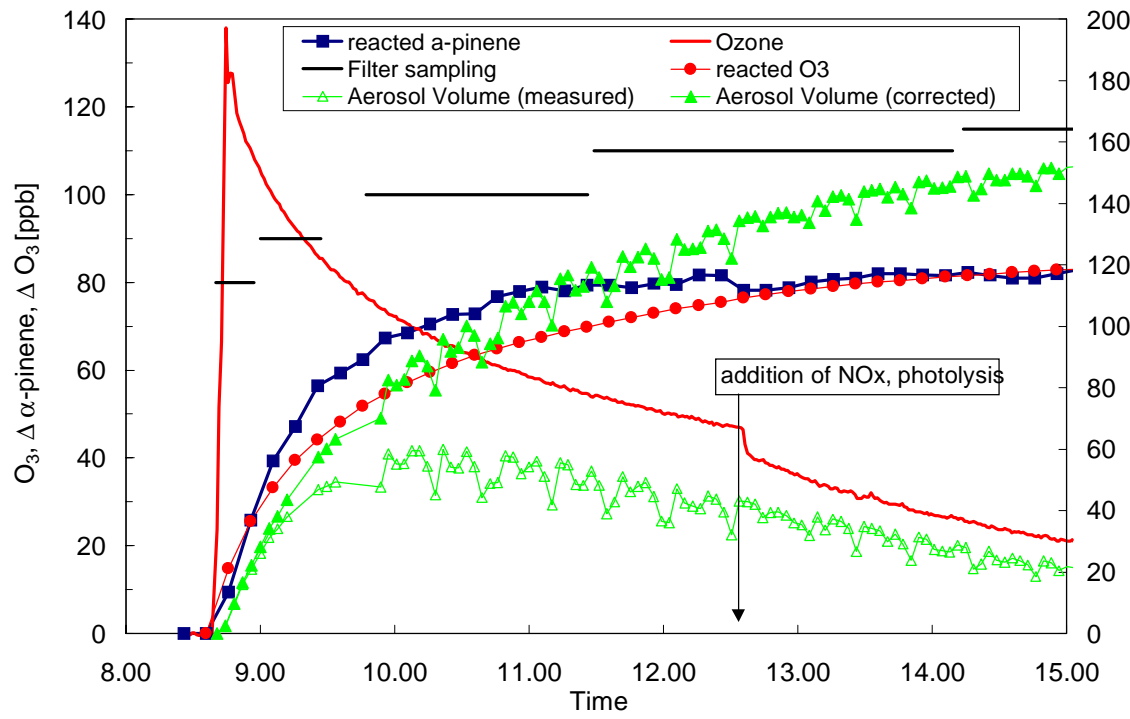

\section{LC-MS analysis of} aerosol particles

R. Winterhalter et al.

Title Page

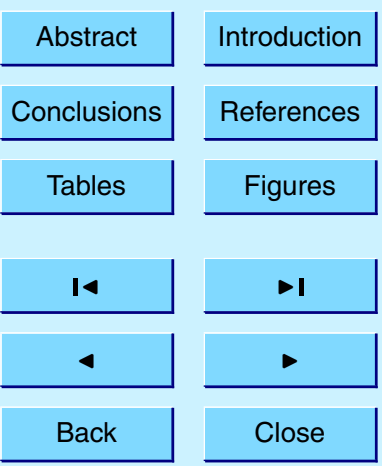

Full Screen / Esc

Fig. 4. (a) Ozonolysis of $\alpha$-pinene (Experiment 0210A). Time profile of ozone, reacted $\alpha$-pinene and reacted ozone, measured and corrected aerosol volume and duration of filter sampling.

Print Version

Interactive Discussion

(C) EGU 2003 
ACPD

3, 1-39, 2003

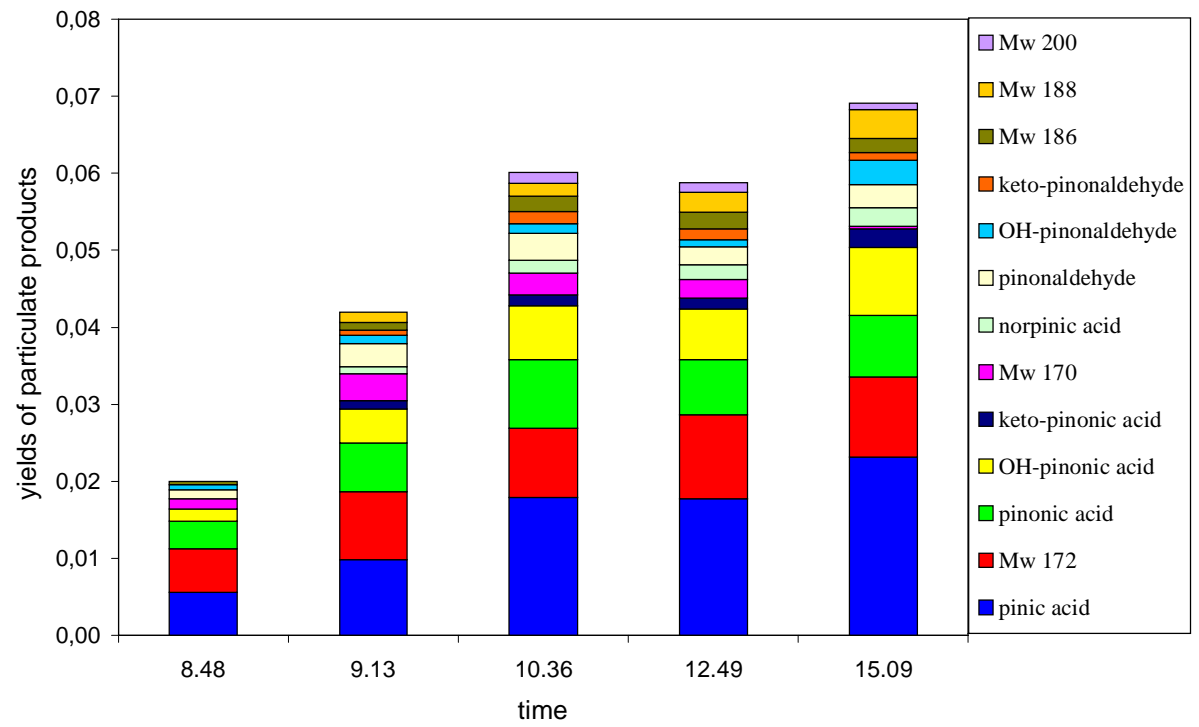

\section{LC-MS analysis of} aerosol particles

R. Winterhalter et al.

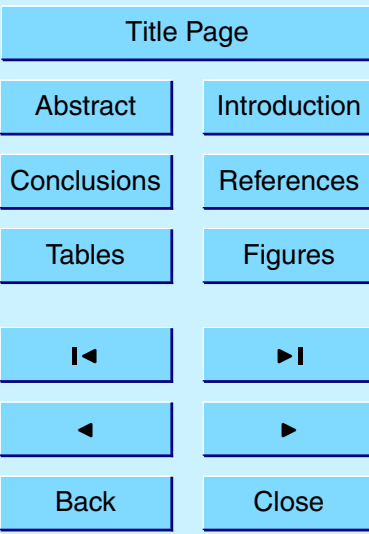

Full Screen / Esc

Fig. 4. (b) Molar yields (versus reacted $\alpha$-pinene) of particulate products.

Print Version

Interactive Discussion

(C) EGU 2003 


\section{ACPD}

3, 1-39, 2003

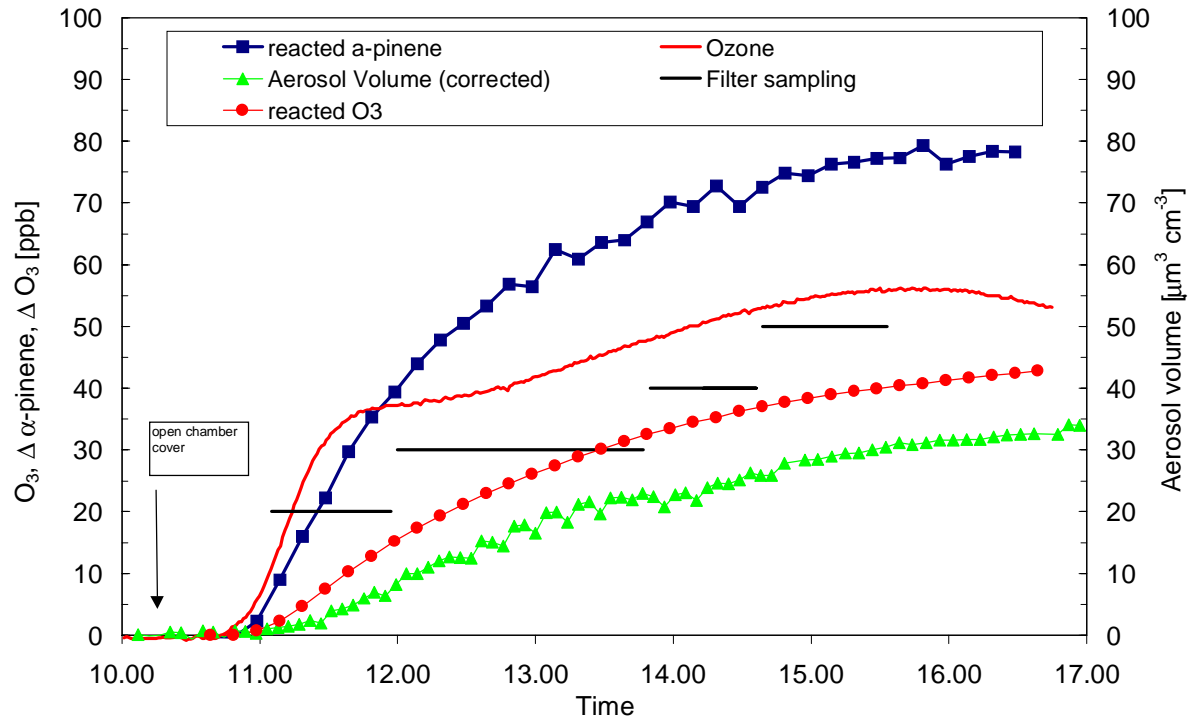

Fig. 5. (a) Photosmog experiment with $\alpha$-pinene (Experiment 2709A). Time profiles of ozone, reacted ozone, reacted $\alpha$-pinene and corrected aerosol volume. The duration of filter sampling is also indicated.

\section{LC-MS analysis of aerosol particles}

R. Winterhalter et al.

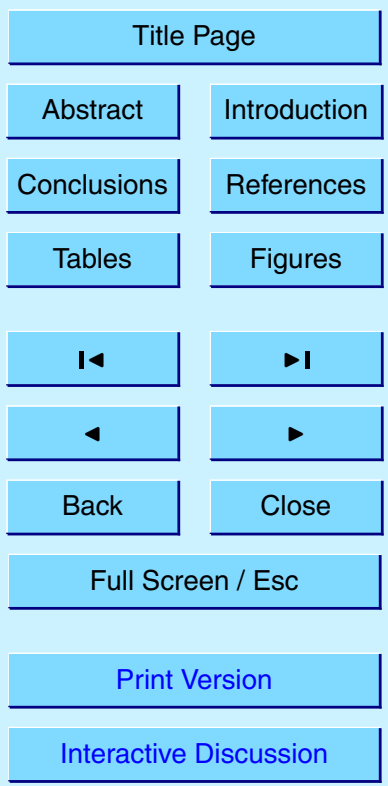

(C) EGU 2003 


\section{ACPD}

3, 1-39, 2003

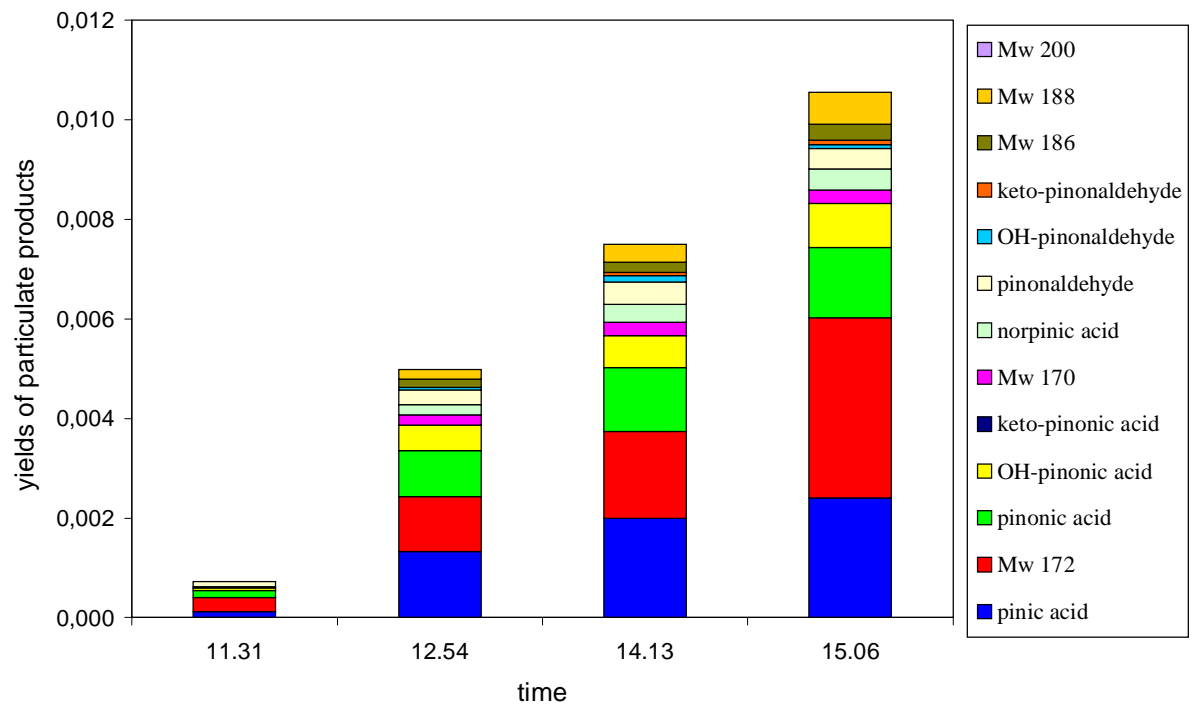

\section{LC-MS analysis of} aerosol particles

R. Winterhalter et al.

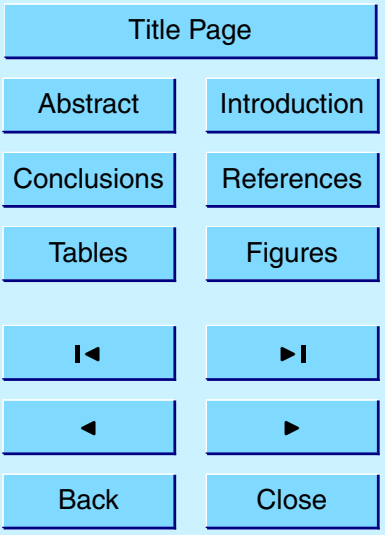

Full Screen / Esc

Fig. 5. (b) Molar yields (versus reacted $\alpha$-pinene) of particulate products.

Print Version

Interactive Discussion

(C) EGU 2003 


\section{ACPD}

3, 1-39, 2003

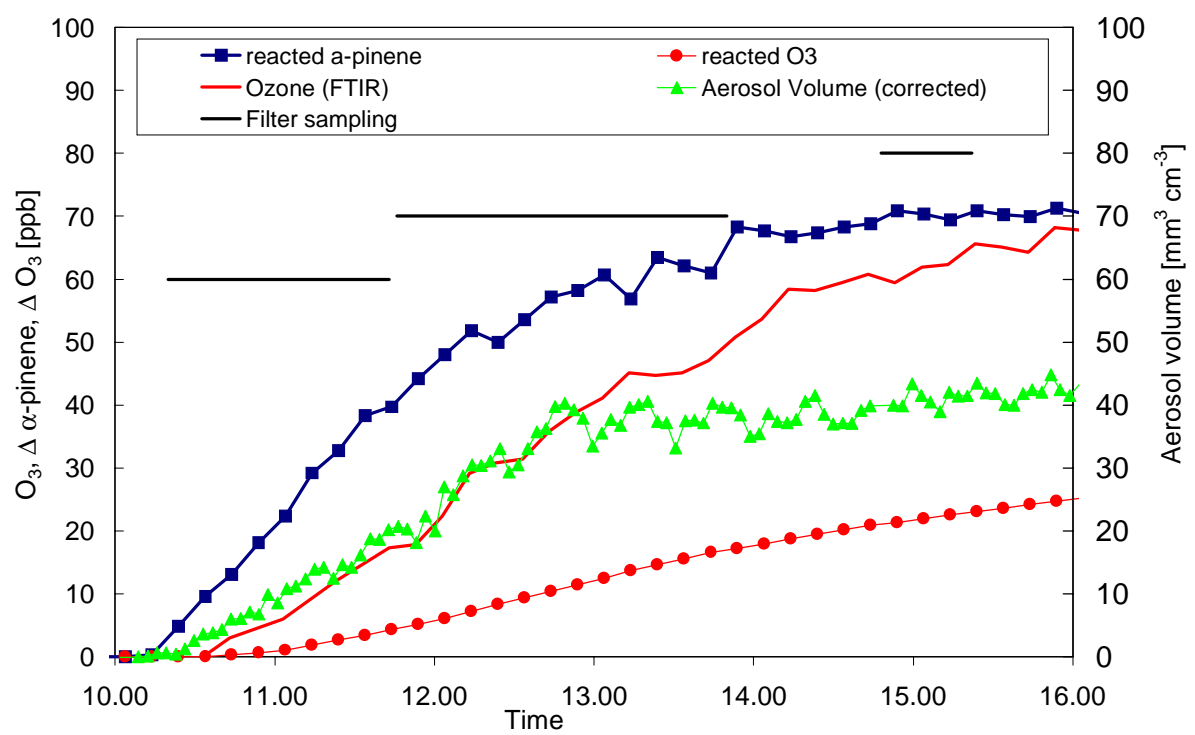

Fig. 6. (a) Reaction of $\alpha$-pinene with $\mathrm{OH}$-radicals, generated by photolysis of $\mathrm{H}_{2} \mathrm{O}_{2}$ (Experiment 0310A). Time profiles of ozone (measured by FTIR-spectroscopy), reacted $\alpha$-pinene and reacted ozone, and corrected aerosol volume. The duration of filter sampling is also indicated.

\section{LC-MS analysis of aerosol particles}

R. Winterhalter et al.

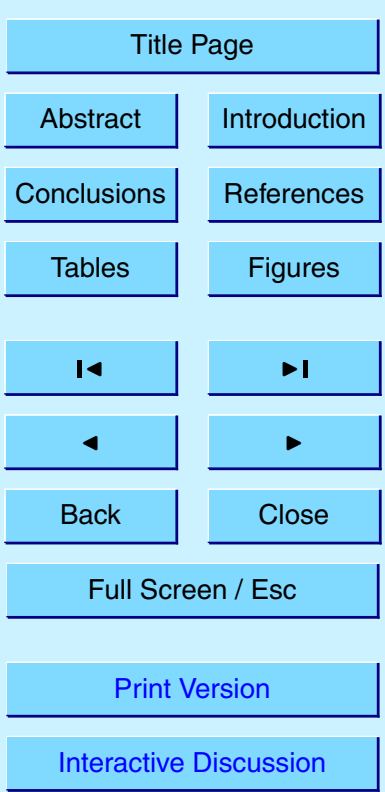

(C) EGU 2003 


\section{ACPD}

3, 1-39, 2003

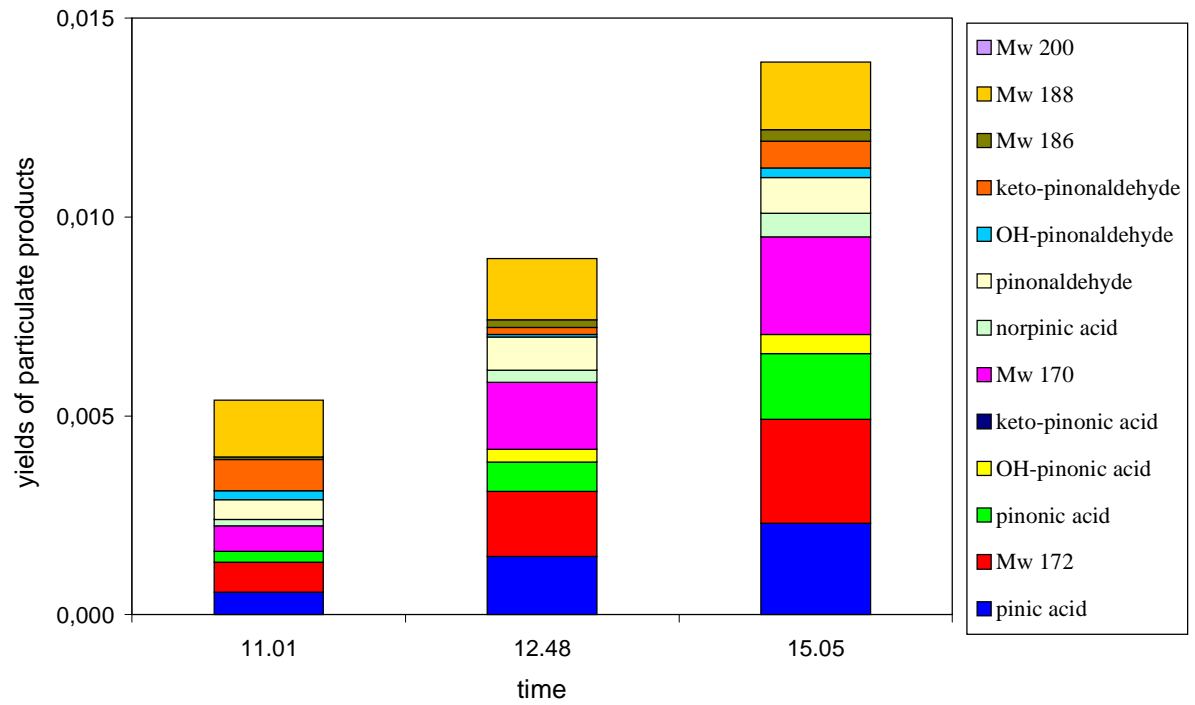

\section{LC-MS analysis of} aerosol particles

R. Winterhalter et al.

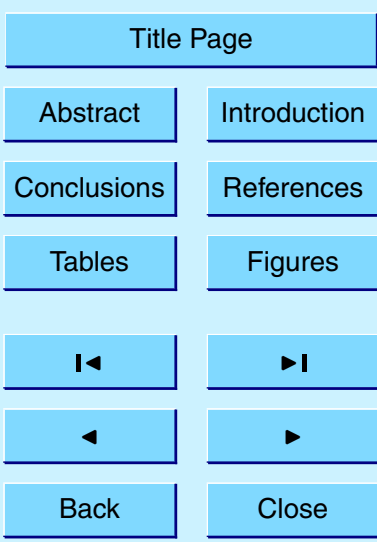

Full Screen / Esc

Fig. 6. (b) Molar yields (versus reacted $\alpha$-pinene) of particulate products.

Print Version

Interactive Discussion

(C) EGU 2003 


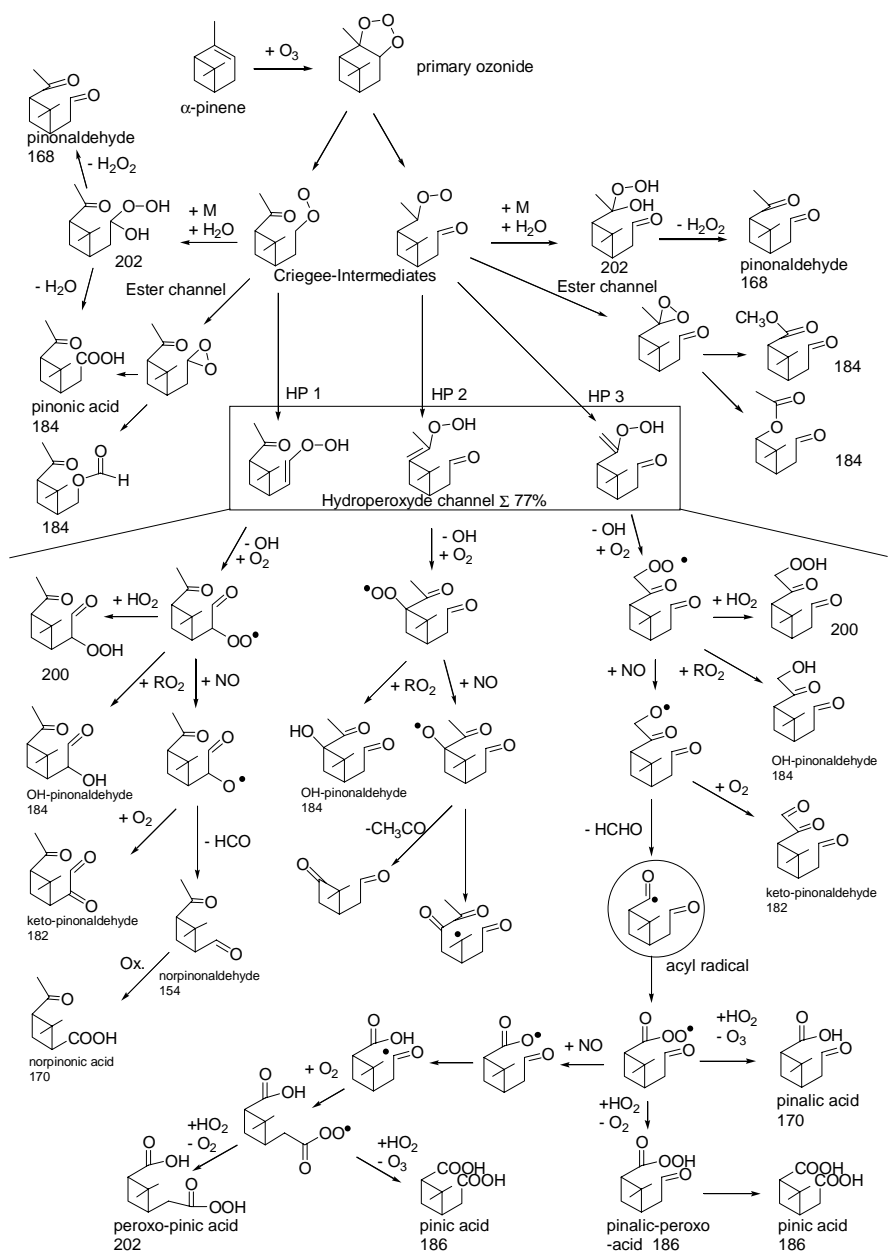

\section{ACPD}

3, 1-39, 2003

\section{LC-MS analysis of} aerosol particles

R. Winterhalter et al.

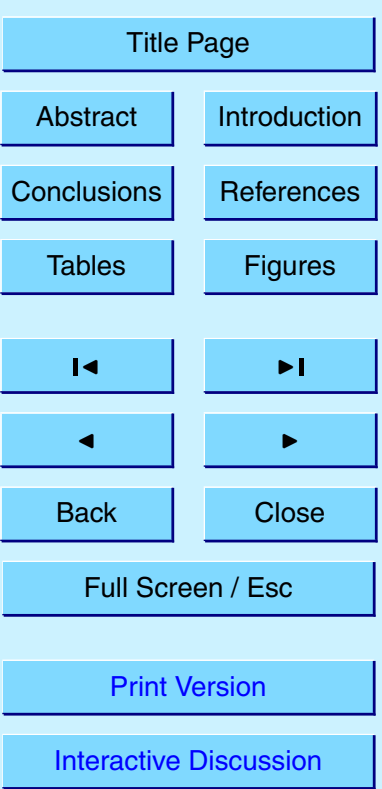

Fig. 7. Reaction mechanism of the reaction of $\alpha$-pinene with ozone.

(C) EGU 2003 


\section{ACPD}

3, 1-39, 2003

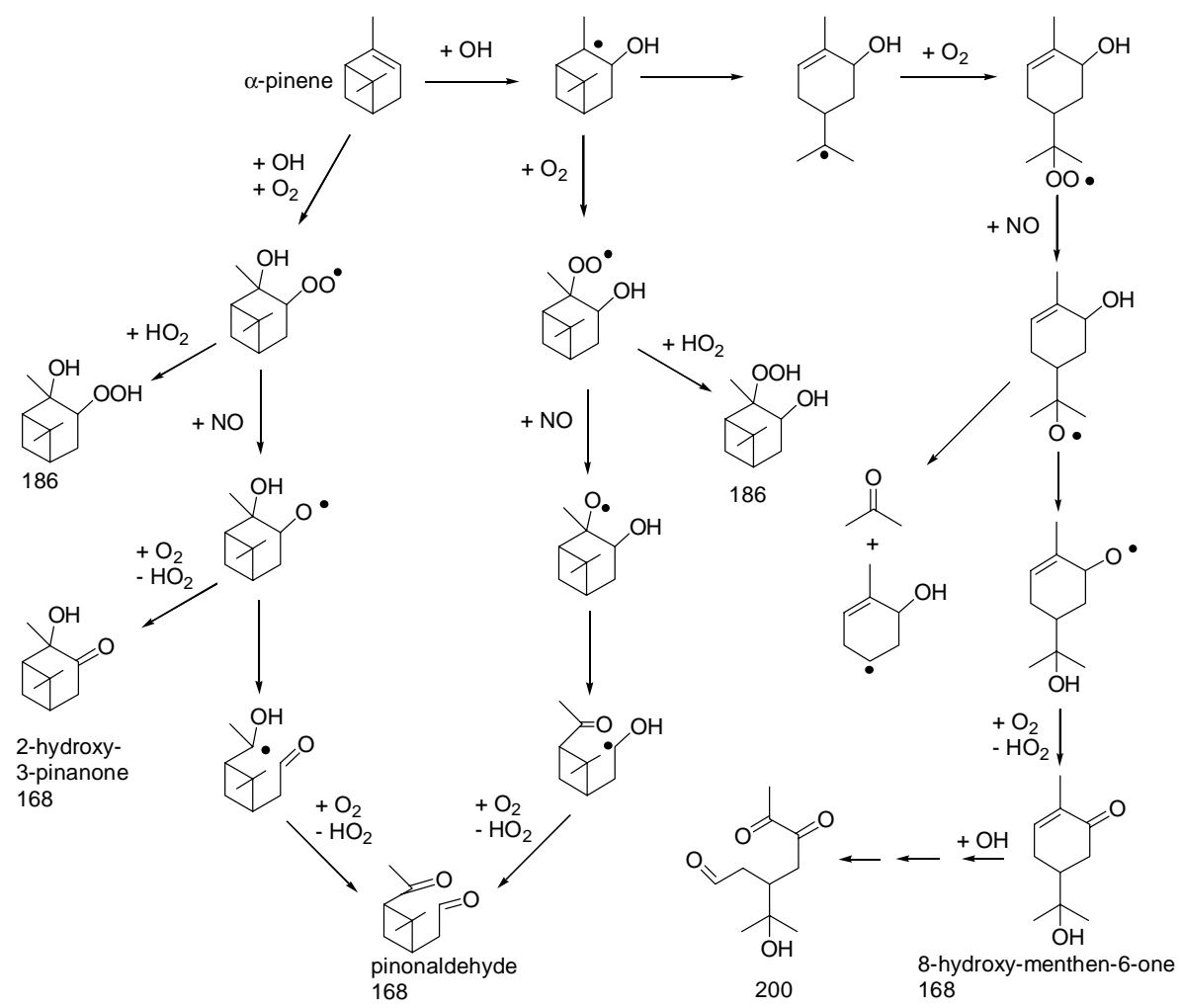

\section{LC-MS analysis of} aerosol particles

R. Winterhalter et al.
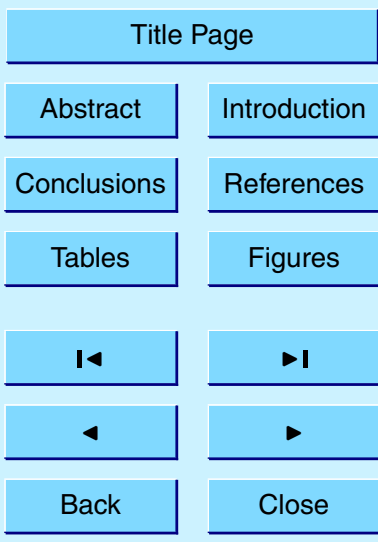

Full Screen / Esc

Print Version

Interactive Discussion

Fig. 8. Reaction mechanism of the $\mathrm{OH}$-radical reaction with $\alpha$-pinene.

(C) EGU 2003 


\section{ACPD}

3, 1-39, 2003
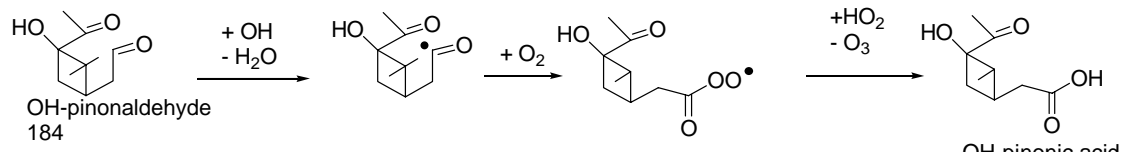

$\mathrm{OH}$-pinonic acid 200
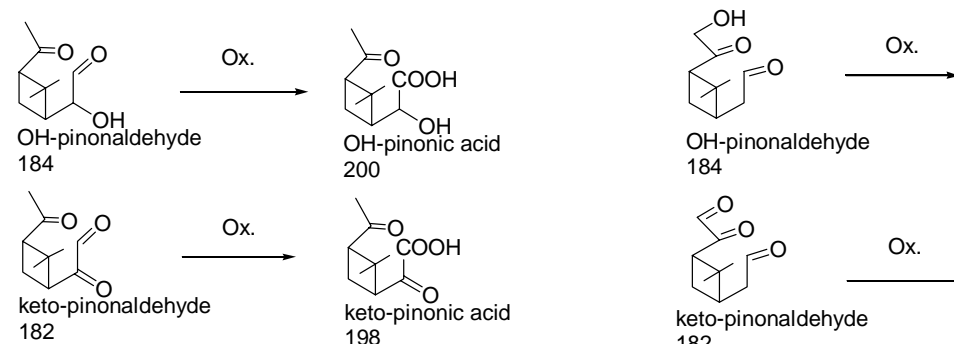

$\mathrm{OH}$-pinonaldehyde

184

$<0$

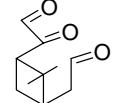

keto-pinonaldehyde 182

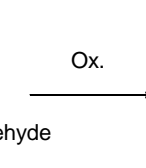
200 $\sum=0$

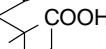

eto-pinonic acid 198

\section{LC-MS analysis of} aerosol particles

R. Winterhalter et al.

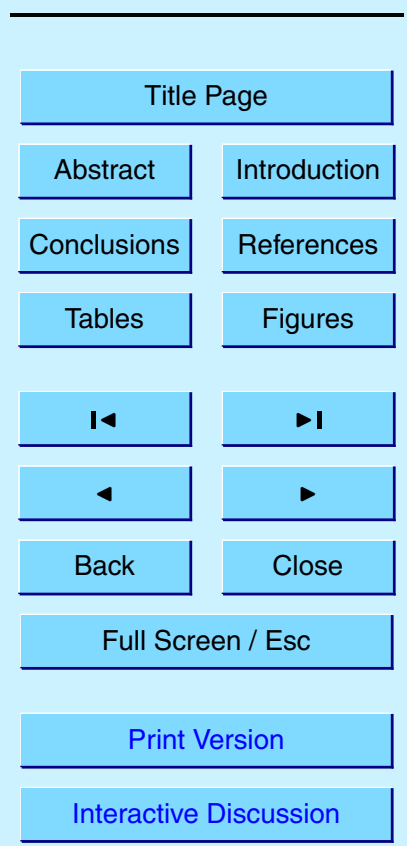

(C) EGU 2003 